\title{
Synergistic Decrease of Clonal Proliferation, Induction of Differentiation, and Apoptosis of Acute Promyelocytic Leukemia Cells after Combined Treatment with Novel 20-epi Vitamin $D_{3}$ Analogs and 9-cis Retinoic Acid
}

\author{
Elena Elstner, ${ }^{*}$ Mariana Linker-Israeli, ${ }^{\ddagger}$ Jennifer Le, ${ }^{\star}$ Tehila Umiel,, ${ }^{\star}$ Patrick Michl, ${ }^{\S}$ Johnathan W. Said, ${ }^{\| \uparrow}$ Lise Binderup, ${ }^{\star *}$ \\ John C. Reed, ${ }^{\ddagger \ddagger}$ and H. Phillip Koeffler*

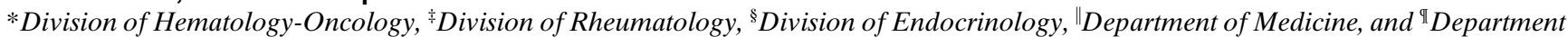 \\ of Pathology, University of California, Los Angeles School of Medicine, Cedars-Sinai Medical Center, Los Angeles, California 90048; \\ **Department of Biology, Leo Pharmaceutical Products, Ballerup, DK-2750 Denmark; and ${ }^{\ddagger}$ The Burnham Institute, La Jolla Cancer \\ Research Foundation, La Jolla, California 92037
}

\begin{abstract}
Patients with acute promyelocytic leukemia (APL) usually relapse after all-trans retinoic acid (RA) treatment because this therapy fails to eradicate the malignant clone. Our data showed that KH 1060 and other 20-epi vitamin $\mathrm{D}_{3}$ analogs alone were potent inhibitors of clonal growth of NB4 cells, an APL cell line $\left(\mathrm{ED}_{50}, \sim 5 \times 10^{-11} \mathrm{M}\right)$. The combination of KH 1060 and 9-cis-RA synergistically and irreversibly enhanced this effect. Neither KH 1060 nor 9-cis-RA $\left(10^{-6} \mathrm{M}\right.$, $3 \mathrm{~d})$ were strong inducers of differentiation of NB4 cells. However, 98\% of the cells underwent differentiation to a mature phenotype with features of both granulocytes and monocytes after exposure to a combination of both compounds. Apoptosis only increased after incubation of NB4 cells with 9-cis-RA alone (28\%) or with a combination of 9-cis-RA plus KH1060 (32\%). Immunohistochemistry showed that the bcl-2 protein decreased from nearly $100 \%$ of the wild-type NB4 cells to $2 \%$ after incubation with a combination of KH 1060 and 9-cis-RA, and the bax protein increased from $50 \%$ of wild-type NB4 cells to $92 \%$ after culture with both analogs $\left(5 \times 10^{-7} \mathrm{M}, 3 \mathrm{~d}\right)$. Western blot analysis paralleled these results. Studies of APL cells from one untreated individual paralleled our results with NB4 cells. Taken together, the data demonstrated that nearly all of the NB4 cells can be irreversibly induced to differentiate terminally when exposed to the combination of KH 1060 and 9-cis-RA. (J. Clin. Invest. 1997. 99:349-360.) Key words: acute promyelocytic leukemia - retinoid (9-cis-retinoic acid) • vitamin $\mathrm{D}_{3}$ analog (KH 1060)
\end{abstract}

This work was presented in part at the 37th annual American Society of Hematology meeting in Seattle, WA on 1-5 December 1995.

Address correspondence to Elena Elstner, Cedars-Sinai Medical Center/UCLA School of Medicine, Davis Bldg. 5033, 8700 Beverly Blvd., Los Angeles, CA 90048. Phone: 310-855-4609; FAX: 310-6599741.

Received for publication 19 July 1996 and accepted in revised form 19 November 1996.

J. Clin. Invest.

(c) The American Society for Clinical Investigation, Inc.

0021-9738/97/01/349/12 \$2.00

Volume 99, Number 2, January 1997, 349-360

\section{Introduction}

Acute promyelocytic leukemia (APL) ${ }^{1}$ is the first neoplasia that was successfully treated with an inducer of differentiation (all-trans retinoic acid, ATRA), resulting in $80 \%$ of these patients achieving a complete remission. However, these remissions have been short-lived because the treatment failed to eradicate completely the malignant clone (1).

Cancer can result from dysregulation of either cellular proliferation, differentiation, and/or apoptosis. APL is composed of a low fraction of cycling leukemic cells compared with other acute myeloid leukemias (2,3); APL cells have prolonged cell survival (4), and in vitro studies have shown that overexpression of promyelocytic myeloid leukemia-retinoic acid receptor (PML-RAR) $\alpha$ protein (pathognomonic for APL) prolongs survival of myeloid precursor cells $(4,5)$. Therefore, induction of apoptosis could be an important goal of APL therapy. Apoptosis (programmed cell death) is the genetically controlled process leading to cellular self elimination $(6,7)$. Susceptibility to apoptosis is regulated by a number of different genes, including bcl-2 and bax oncogenes. The mitochondrial protein bcl-2 suppresses or delays the onset of apoptosis $(8,9)$. In contrast, protooncogene bax, which encodes a membrane $(\alpha)$ and two forms of cytosolic proteins ( $\beta$ and $\gamma$ ), accelerates apoptotic death and counters the death repressor activity of bcl-2 (10). To eliminate rapidly and efficiently the APL clone, the combination of potent differentiation- and/or apoptosis-inducing compounds, which mediate their actions through different receptors and signal pathways, may be useful.

Unlike ATRA, which binds only RARs, 9-cis retinoic acid (RA), a stereoisomer of ATRA, is a high affinity ligand for both RARs and retinoid X receptors (RXRs). In the presence of 9-cis-RA, RXRs form RAR/RXR heterodimers and/or RXR/RXR homodimers $(11,12)$. However, the 9-cis-RA was only slightly more potent than ATRA in inducing myeloid differentiation of myeloid leukemia cells in vitro $(13,14)$, and does not reverse clinically acquired retinoid resistance (15).

The active vitamin $\mathrm{D}_{3}$ metabolite, 1,25-dihydroxyvitamin $\mathrm{D}_{3}(1,25 \mathrm{D})$, is also a differentiation-inducing agent and an important modulator of cellular proliferation for a number of malignant cell types. This biological response is mediated by

1. Abbreviations used in this paper: APL, acute promyelocytic leukemia; ATRA, all-trans-retinoic acid; PML, promyelocytic myeloid leukemia gene; RARs, retinoic acid receptors; RXRs, retinoid X receptors; $1,25 \mathrm{D}, 1,25$-dihydroxyvitamin $\mathrm{D}_{3}$; VDR, vitamin $\mathrm{D}_{3}$ receptor; NBT, nitroblue tetrazolium; NSE, $\alpha$-naphthyl acetate esterase; MPO, myeloperoxidase; CI, combination index. 


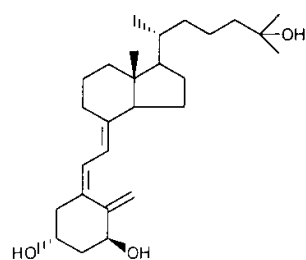

$1,25(\mathrm{OH})_{2} \mathrm{D}_{3}$

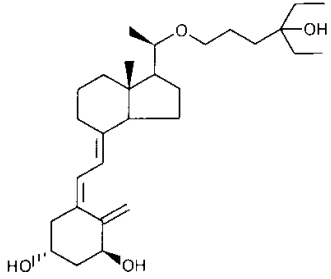

KH 1060

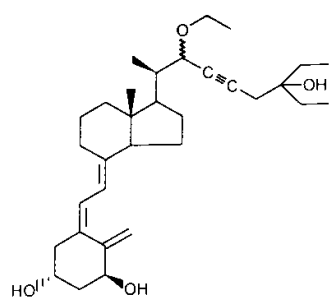

CB 1093

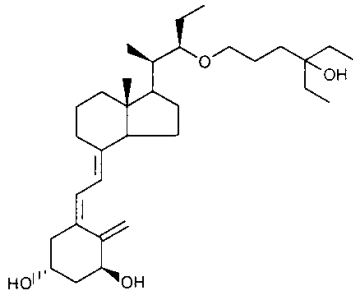

KH 1266
Figure 1. Chemical structure of 20-epi vitamin $\mathrm{D}_{3}$ analogs.

binding to nuclear receptors for 1,25D (VDR) that belong to the same steroid receptor superfamily as RARs and RXRs (16). This ligand-inducible transcription factor mediates the $1,25 \mathrm{D}$ signaling pathway by binding to specific response elements in the promoter region of genes regulated by $1,25 \mathrm{D}$. The VDR can function as a homodimer (VDR-VDR), but probably more often heterodimerizes with RXR (17-20). The clinical use of $1,25 \mathrm{D}$ for leukemia is limited due not only to its calcemic side-effects, but also because $1,25 \mathrm{D}$ alone fails to eliminate the leukemic clone (21-23).

The KH 1060, CB1093, and KH1266 (Fig. 1) belong to the family of 20-epi vitamin $\mathrm{D}_{3}$ analogs. These compounds are considerably more potent in vitro than $1,25 \mathrm{D}$ in their inhibition of clonal growth of leukemic (24-26), breast (27), and prostate (28-29) cancer cell lines, but these analogs have less or the same calcemic effects as 1,25D (29).

Recently, evidence has accumulated that ligands that bind to RARs are sufficient to inhibit proliferation and to induce differentiation of promyelocytic leukemic cells, but cannot cause apoptosis. Induction of apoptosis may require ligandactivation of RXRs (30-33). Therefore, the combination of 9-cis-RA and 1,25D analogs may activate an overlapping set of genes that induce irreversible myeloid differentiation and apoptosis. This combination therapy, rather than a retinoid alone, may more effectively eradicate the APL clone.

In this study, we pursued two related aims. First, find a potent combination of a 20-epi vitamin $\mathrm{D}_{3}$ analog and a retinoid that could mediate irreversible inhibition in vitro of proliferation of NB4 cells and fresh APL blasts. Second, study the cross talk between retinoids and 20 -epi vitamin $D_{3}$ analogs required to inhibit proliferation and induce differentiation and apoptosis of APL cells.

\section{Methods}

Cells. The NB4 promyelocytic cell line with a reciprocal chromosomal translocation $t(15,17)$ resulting in the fusion of PML with RAR alpha gene, was established from a patient with APL in relapse who had received ATRA (34). The cells, generously provided by Dr. Lan- otte (I.N.S.E.R.M., Hôpital Saint-Louis, Paris, France), were cultured in RPMI (Sigma Chemical Co., St. Louis, MO) with 10\% FCS (Irvine Scientific, Santa Ana, CA) in culture flasks (Costar Corp., Cambridge, MA).

Fresh mononuclear cells (Ficoll-Paque; Pharmacia Biotechnology, Uppsala, Sweden) were isolated from blood drawn at diagnosis, after informed consent, from a 62-yr-old female with APL with $80 \%$ promyelocytes in her peripheral blood; these cells had the typical $t(15,17)$ of APL. The mononuclear cells were cultured overnight in DMEM with $10 \%$ FCS and $10 \%$ autologous plasma. The cells were washed and placed in DMEM with $10 \%$ FCS with various compounds and cultured for $3 \mathrm{~d}$ before analysis.

Vitamin $D_{3}$ analogs and retinoids. The parental compound $[1 \alpha, 25$ $(\mathrm{OH})_{2} \mathrm{D}_{3}$ ] (generous gift of Dr. M. Uskokovic, Hoffmann LaRoche, Nutley, NJ) was dissolved in absolute ethanol $\left(10^{-3} \mathrm{M}\right)$ and stored at $-20^{\circ} \mathrm{C}$ protected from light. The 20 -epi vitamin $\mathrm{D}_{3}$ analogs, $\mathrm{KH}$ 1060, [20-epi-22oxa-24a,26a,27a-tri-homo-1 $\alpha, 25(\mathrm{OH})_{2} \mathrm{D}_{3}$ ], KH1266, [1(S),3(R)-dihydroxy-20(R)-\{1(R)-(4-hydroxy-4-ethyl-1-hexyloxy)1-propyl\}-9,10-seco-pregna-5(Z), 7(E),10(19)triene], and CB1093, [20-epi-22-ethoxy-23-yne-24a,26a,27a-tri-homo1 $\alpha, 25(\mathrm{OH})_{2} \mathrm{D}_{3}$ ] (synthesized in the Department of Chemical Research, Leo Pharmaceutical Products) were dissolved in isopropanol at $4 \times 10^{-3} \mathrm{M}$ as a stock solution and stored at $-20^{\circ} \mathrm{C}$ protected from light. The following retinoids were dissolved in DMSO at $10^{-2} \mathrm{M}$, stored at $-80^{\circ} \mathrm{C}$, and protected from light: 9-cis-RA, (generous gift of Dr. H. Klaus, Hoffmann-La Roche, Basel, Switzerland), ATRA (Sigma Chemical Co.), as well as SR11238 and SR11236 (generous gifts of Dr. M. Dawson, Bio-Organic Chemistry Laboratory, SRI International, Menlo Park, CA).

Studies of induction of differentiation. Differentiation of NB4 was assessed by the ability of the cells to produce superoxide as measured by reduction of nitroblue tetrazolium (NBT) (35), by staining for $\alpha$-naphthyl acetate esterase (NSE) (Sigma Chemical Co.), by morphology as detected on cytospin preparations stained with Diff-Quick Stain Set (Baxter Healthcare Corp., Miami, FL) and by analysis of several membrane-bound differentiation markers (CD11b, CD11c, CD14, HLA-DR, CD16, CD69) using one- and two-color immunofluorescence. The latter was performed as described (26). Briefly, cells were incubated at $4^{\circ} \mathrm{C}$ for $60 \mathrm{~min}$ in $10 \%$ human $\mathrm{AB}$ serum (Sigma Chemical Co.) to block Fc receptors, and then stained with either one- or two-color FITC-conjugated murine monoclonal antibodies to CD11c, CD14, CD16, CD69, HLA-DR and/or with propidium iodide (PE)-conjugated $\mathrm{mAb}$ to human $\mathrm{CD} 11 \mathrm{~b}$. The two-color immunofluorescence for CD14/HLA-DR used PE-conjugated CD14 mAb. All mAbs were purchased from Becton Dickinson \& Co. (Mountain View, CA). Control samples were incubated with FITC-conjugated mouse IgG1 isotype control (Becton Dickinson \& Co.). Analysis of fluorescence was performed on FACScan ${ }^{\circledR}$ flow cytometry, using a LYSIS II program (Becton Dickinson \& Co.).

Cell cycle analysis by flow cytometry. Cell cycle was analyzed by flow cytometry after $3 \mathrm{~d}$ of incubation of NB4 either with or without analogs $\left(10^{-6} \mathrm{M}\right)$ as described (26). Briefly, the NB4 cells cultured for $3 \mathrm{~d}$, were gently removed with a disposable cell scraper (Costar Corp.), washed in DPBS, fixed in methanol, and incubated for $30 \mathrm{~min}$ at $4^{\circ} \mathrm{C}$ in the dark with a solution of $5 \mu \mathrm{g} / \mathrm{ml}$ propidium iodide, $1 \mathrm{mg} / \mathrm{ml}$ RNase (Sigma Chemical Co.), and 0.1\% Nonidet P-40 (Sigma Chemical Co.). Analysis was performed immediately after staining using the CELLFit program (Becton Dickinson \& Co.) whereby the S-phase was calculated with an RFit model.

Clonogenic assay in soft agar. The NB4 cells were cultured in a two-layer soft agar system for $10 \mathrm{~d}$ without adding any growth factors, as previously described, and colonies were counted using an inverted microscope (36). The analogs were added to the upper layer of agar on day 0 . For analysis of the reversibility of the effects of the analogs, the cells were cultured in suspension culture with and without analogs. On the $3 \mathrm{rd} \mathrm{d}$, the cells were very gently removed with a disposable cell scraper and washed twice in culture medium containing $10 \%$ FCS to completely remove the test-analogs; the cells were then counted and clonogenic assay was performed. 
Apoptosis. Apoptosis of NB4 cells was assessed by changes in cell morphology and by analysis of DNA fragmentation. Morphologically, NB4 cells undergoing apoptosis possess many prominent features such as intense staining, highly condensed and/or fragmented nuclear chromatin, a general decrease in overall cell size, and cellular fragmentation into apoptotic bodies (31). These features make apoptotic cells relatively easy to distinguish from necrotic cells. The NB4 cells, after exposure to analogs, were washed with DPBS and analyzed for apoptosis on cytospin preparations stained with Diff-Quick Stain Set. Apoptotic cells were enumerated in $\sim 300$ cells by light microscopy. DNA fragmentation was also confirmed by a modification of the method of Sellins and Cohen (37), as described previously (27).

Detection of bcl-2 and bax by immunohistochemistry. NB4 cells that had been cultured in liquid media with and without analogs for $3 \mathrm{~d}$, were placed on glass slides by cytocentrifugation, fixed in cold buffered methanol/acetone, and rinsed with normal swine serum for 10 min. The bcl-2 protein was detected with a murine monoclonal anti-human bcl-2 (DAKO Corp., Carpinteria, CA) at a 1:300 dilution as described previously (26). Intracellular bax protein was detected with a rabbit polyclonal anti-human bax antibody $(26,38)$. Briefly, cells were fixed and permeabilized in $1 \%$ paraformaldehyde and icecold $70 \%$ ethanol. The pelleted cells were preblocked in $4 \%$ human $\mathrm{AB}$ serum for $30 \mathrm{~min}$ at $4^{\circ} \mathrm{C}$, and then rabbit anti-human bax polyclonal antibody (1:500) was added. Incubation with the primary antibody (30 min) was followed by exposure to horseradish peroxidaseconjugated rabbit anti-mouse antibody (DAKO Corp.) diluted 1:50 in PBS and the 3,3'-diaminobenzidine substrate. The slides were counterstained with methyl green. Control slides substituted PBS for the primary antibody.

Detection of bax cellular content by flow cytometry. After staining with a rabbit polyclonal anti-human bax antibody as described above, and extensive washing, the cells were incubated with FITCconjugated goat anti-rabbit IgG (1:100) (Organon Teknika-Cappel, West Chester, PA). Control samples were incubated with PBS instead of primary antibody before incubation with FITC-conjugated goat anti-rabbit IgG. Analysis was performed with a FACScan ${ }^{\circledR}$ cytometer, using the LYSYS II program, and by fluorescence microscopy.

Detection of bcl-2, bax, and myeloperoxidase cellular content by immunoblotting. Western blot analysis was performed with polyclonal rabbit anti-bcl-2 antibody N19 (Santa Cruz Biotechnology, Santa Cruz, CA), which reacts with the human bcl-2 protein of $26 \mathrm{kD}$ $(39,40)$, a rabbit polyclonal anti-bax antibody that reacts with the human bax protein of $21 \mathrm{kD}$, and rabbit polyclonal anti-myeloperoxidase (MPO) antibody, which recognizes the $55 \mathrm{kD}$ MPO protein (41). Briefly, an equal number of cells $\left(10^{6}\right)$ were lysed in RIPA buffer $(1 \%$ NP-40, $0.5 \%$ sodium deoxycholate, $0.1 \%$ SDS) containing the freshly added protease inhibitors aprotinin $(30 \mu \mathrm{g} / \mathrm{ml})$, PMSF $(100 \mu \mathrm{g} / \mathrm{ml})$, and sodium orthovanadate $(100 \mathrm{mM})$. After equalizing the amount of protein by a fluorescence protein assay (Bio-Rad Laboratories, Hercules, CA), cell lysate (30 $\mu \mathrm{g}$ of protein per lane) was mixed with an equal volume of sample buffer (125 mM Tris-HCl, $\mathrm{pH} 6.8,4 \%$ SDS, $20 \%$ glycerol, $10 \%$ 2-beta-mercaptoethanol, $0.02 \%$ bromophenol blue), denatured for $90 \mathrm{~s}$ at $100^{\circ} \mathrm{C}$, and electrophoresed on a $7.5 \%$ SDS-PAGE for MPO, and on a $12 \%$ gel for bcl-2 and bax. Proteins were electrophoretically transferred onto immobilon membranes (Millipore Corp., Bedford, MA). Blocking was performed for $1 \mathrm{~h}$ with TBS including $0.05 \%$ Tween- 20 and $5 \%$ skim milk. The membranes were sequentially incubated for $45 \mathrm{~min}$ with a primary monoclonal murine anti-bcl-2 antibody (1:50), with a polyclonal rabbit anti-human bax antibody (1:500) and a polyclonal rabbit anti-human antibody against MPO (1:1,000). After two washes with TBS/0.05\% Tween-20, the membranes were incubated for $30 \mathrm{~min}$ with horseradish peroxidase-conjugated sheep anti-mouse or -rabbit IgG (Amersham Corp., Arlington Heights, IL). After four subsequent washes, the bound antibody was visualized with enhanced chemiluminescence reagents (Amersham Corp.), and the membranes were immediately exposed to x-ray film. Membranes were stored wet wrapped in SaranWrap ${ }^{\circledR}$ in the refrigerator $\left(2-8^{\circ} \mathrm{C}\right)$ after immunodetection.
For detection of a second protein, the membranes were incubated in stripping buffer (100 mM 2-beta-mercaptoethanol, $2 \%$ sodium dodecyl sulfate, $62.5 \mathrm{mM}$ Tris- $\mathrm{HCl}, \mathrm{pH} 6.7$ ) at $50^{\circ} \mathrm{C}$ for $30 \mathrm{~min}$ with occasional agitation, washed twice for $10 \mathrm{~min}$ in TBS at room temperature using large volumes of wash buffer and blocked with 5\% blocking reagent TBS for $1 \mathrm{~h}$ at room temperature. After this procedure, immunodetection was performed as described above. Densitometric measurements were done by using "UVP gel analysis suite."

Phagocytosis. The NB4 cells after exposure to analogs were washed twice with PBS, cultured in regular medium for $1 \mathrm{~d}$, and then tested for their ability to phagocytose yeast. The method developed for studying phagocytosis has been described in detail by Territo and Cline (42). Briefly, Candida albicans were opsonized in $10 \%$ human AB serum. A 5:1 ratio of $C$. albicans to leukemic cells was incubated at $37^{\circ} \mathrm{C}$ for $30 \mathrm{~min}$. The cells were stained with Diff-Quick Stain Set, and the percentage of cells completely ingesting one or more yeasts was determined microscopically.

Incubation with $\gamma$-interferon. After $3 \mathrm{~d}$ of cultivation either with or without analogs, the cells were collected from flasks, washed twice in culture medium to remove the analogs, and replaced in fresh medium. $100 \mathrm{U} / \mathrm{ml} \gamma$-IFN (Boehringer Mannheim Biochemicals, Indianapolis, IN) were added to NB4 cells, and cells were incubated in suspension culture for $2 \mathrm{~d}$. Control NB4 cells (untreated or cultured with either KH 1060, 9-cis-RA, or both) were incubated for the same duration as the experimental cells in culture medium without $\gamma$-IFN.

Analysis of effects of combination of drugs. Isobologram analysis was used to evaluate the effect of combinations of drugs on leukemic cells (43). Dose-dependent activities were determined separately for each compound, and then the effects were determined for the combination of one compound held at a fixed concentration and the other at different dilutions. The interaction of two compounds was quantified by determining the combination index (CI) according to the classic isobologram equation (44): $\mathrm{CI}=(D)_{1} /(D x)_{1}+(D)_{2} /(D x)_{2}$, where $D x$ is the dose of one compound alone required to produce an effect, and $(D)_{1}$ and $(D)_{2}$ are the doses of both compounds that produce the same effect. From this analysis, the combined effects of two analogs can be assessed as either summation (additive or zero interaction), indicated as $\mathrm{CI}=1$; synergism, indicated as $\mathrm{CI}<1$; or antagonism, indicated as $\mathrm{CI}>1$. Other statistical data were handled using the Student's $t$ test.

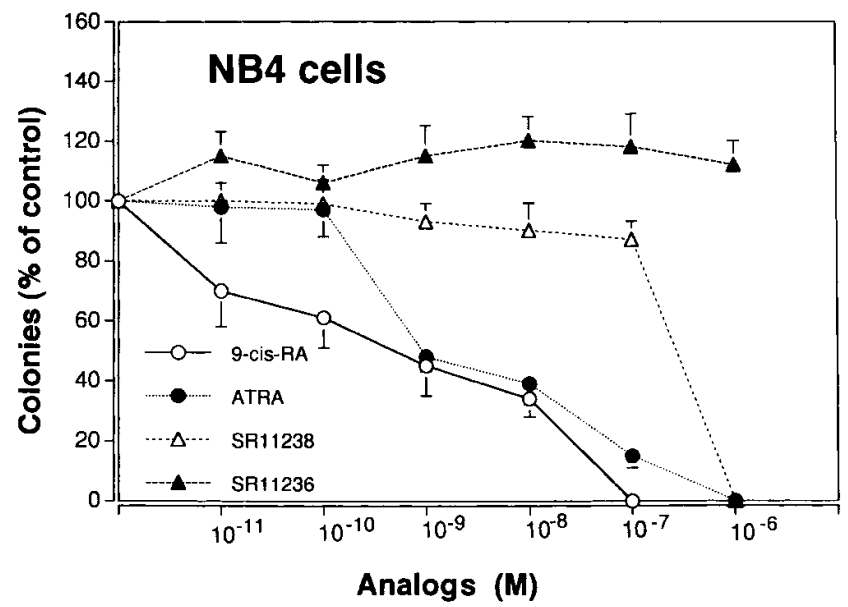

Figure 2. Retinoids: dose-response effects of retinoids on clonal proliferation of NB4 cells in soft agar culture. Results are expressed as a mean percent \pm SD of control plates containing no analog. Each point represents a mean of at least three experiments with each experimental point having triplicate dishes. The compounds were added to the cells on day 0 . 


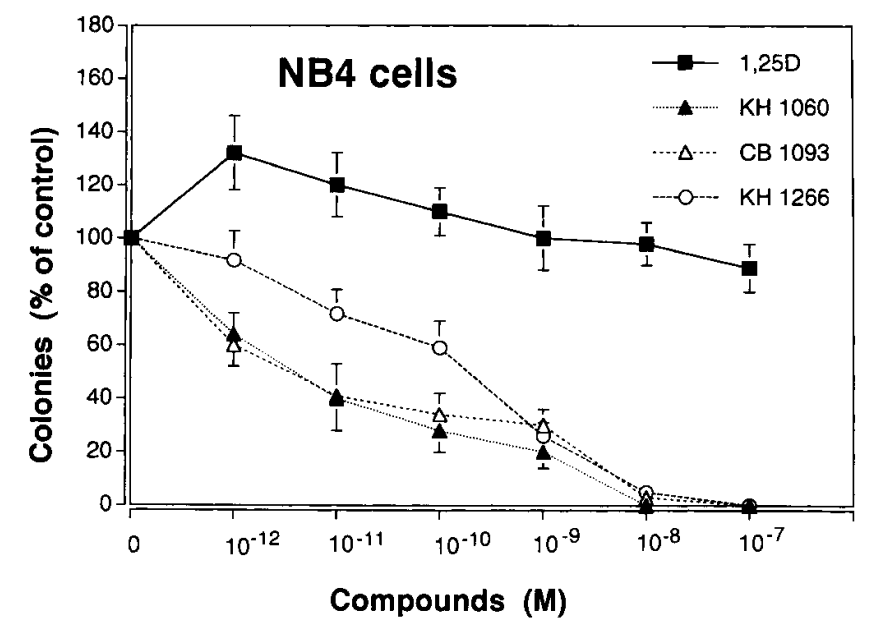

Figure 3. Vitamin $\mathrm{D}_{3}$ compounds: dose-response effects on clonal proliferation of NB4 cells in soft agar culture. Results are expressed as a mean percent \pm SD of control plates containing no analog. Each point represents a mean of at least three experiments with each experimental point having triplicate dishes. The compounds were added to the cells on day 0 .

\section{Results}

Clonal proliferation of NB4 cells was synergistically decreased by the combination of KH 1060 and 9-cis-RA

To study the effects of different analogs or a combination of analogs on clonogenic growth of NB4 cells, the two-layer soft agar system was performed. The SR11236 (RXR $\alpha$-specific analog) and SR11238 (analog with anti-AP-1 activity) had little effect at $10^{-11}-10^{-7} \mathrm{M}$ on inhibition of clonal proliferation of NB4 cells in soft agar (Fig. 2). In contrast, 9-cis-RA (RAR/RXR, RXR/RXR-specific ligand) and ATRA (RAR/RXR binding ligand) showed a dose-dependent inhibition. The effective dose inhibiting $50 \%$ of colonies $\left(\mathrm{ED}_{50}\right)$ occurred at $10^{-9} \mathrm{M}$ for ATRA and $5 \times 10^{-9} \mathrm{M}$ for 9-cis-RA (Fig. 2).

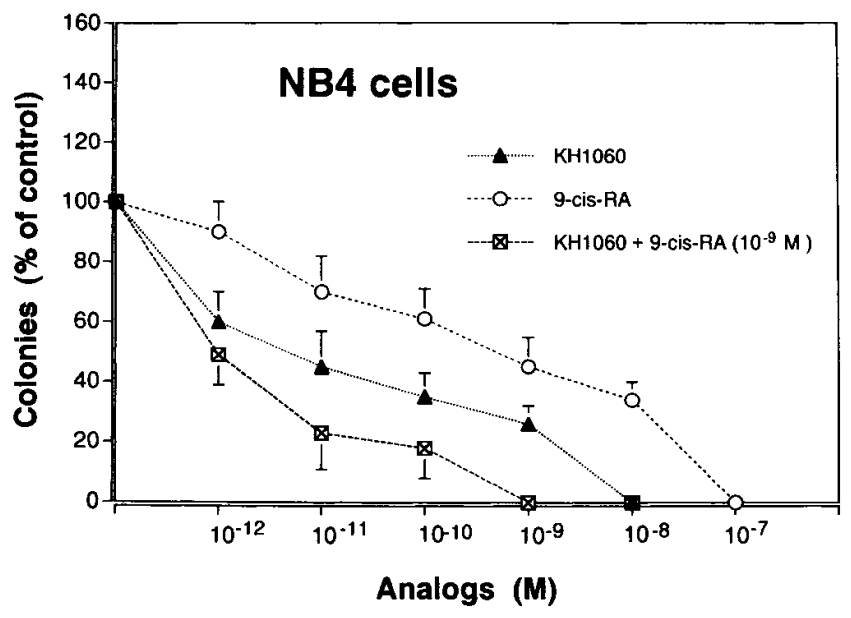

Figure 4. Dose-response effects of either KH 1060, 9-cis-RA, or the combination of both on clonal proliferation of NB4 cells in soft agar culture. Results are expressed as a mean percent \pm SD of control plates containing no analog. Each point represents a mean of at least three experiments with each experimental point having triplicate dishes. The compounds were added to the cells on day 0 .

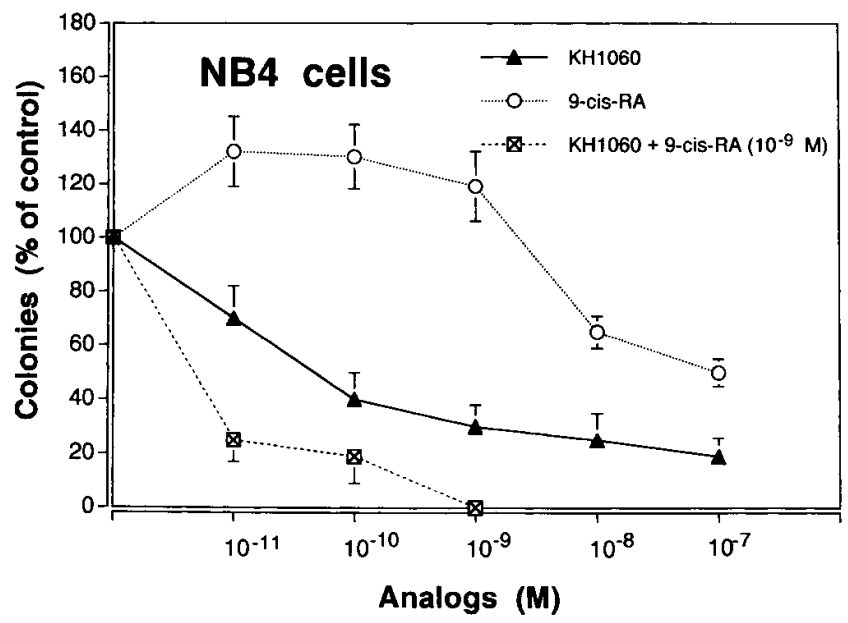

Figure 5. Clonal inhibition of NB4 cells after pulse exposure (3 d) to KH 1060, 9-cis-RA, or both compounds. NB4 cells were exposed in liquid culture to either KH 1060, 9-cis-RA, or both KH $1060\left(10^{-12}\right.$ $\left.10^{-7} \mathrm{M}\right)$ and 9-cis-RA $\left(10^{-9} \mathrm{M}\right)$, washed, plated in soft agar, and resulting colonies counted. Each point represents a mean \pm SD of at least three experiments with each experimental point having triplicate dishes.

The 1,25D showed no inhibition, but rather slightly stimulated clonal proliferation of NB4 cells at $10^{-12}-10^{-8} \mathrm{M}$ (Fig. 2). In contrast, the 20-epi-vitamin $\mathrm{D}_{3}$ analogs (KH 1060, CB1093, and KH1266) were potent inhibitors of NB4 clonal proliferation with an $\mathrm{ED}_{50}$ of $5 \times 10^{-11}, 5 \times 10^{-11}$, and $5 \times 10^{-9} \mathrm{M}$, respectively (Fig. 3). The combination of the most potent analogs, 9-cis-RA $\left(10^{-9} \mathrm{M}\right)$ with $\mathrm{KH} 1060\left(10^{-11}-10^{-9} \mathrm{M}\right)$ produced a synergistic effect $(\mathrm{CI}<1)$ on inhibition of clonal growth $\left(\mathrm{ED}_{50}=10^{-12} \mathrm{M}\right)$ (Fig. 4). Clonal growth was nearly undetectable when both analogs were combined at $10^{-9} \mathrm{M}$ (Fig. 4).

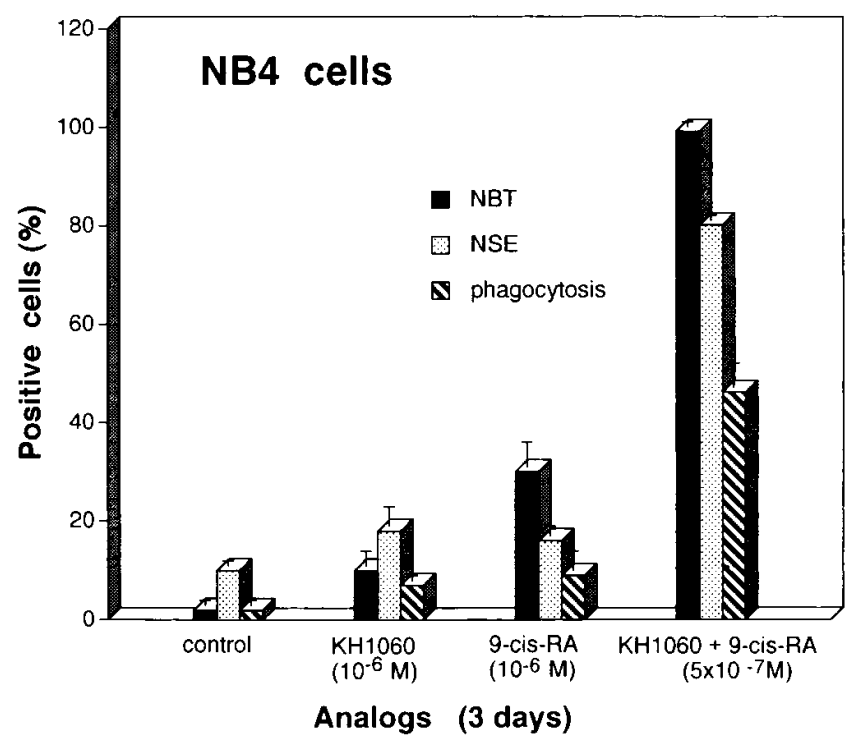

Figure 6. Induction of differentiation of NB4 cells, as measured by their abilities to reduce NBT, phagocytize $C$. albicans, and stain with $\alpha$-naphthyl acetate esterase, after culture with either KH 1060 $\left(10^{-6} \mathrm{M}, 3 \mathrm{~d}\right), 9$-cis-RA $\left(10^{-6} \mathrm{M}, 3 \mathrm{~d}\right)$, or both compounds $\left(5 \times 10^{-7} \mathrm{M}\right.$, $3 \mathrm{~d})$. Results represent mean $\pm \mathrm{SD}$ of three or more experiments. 

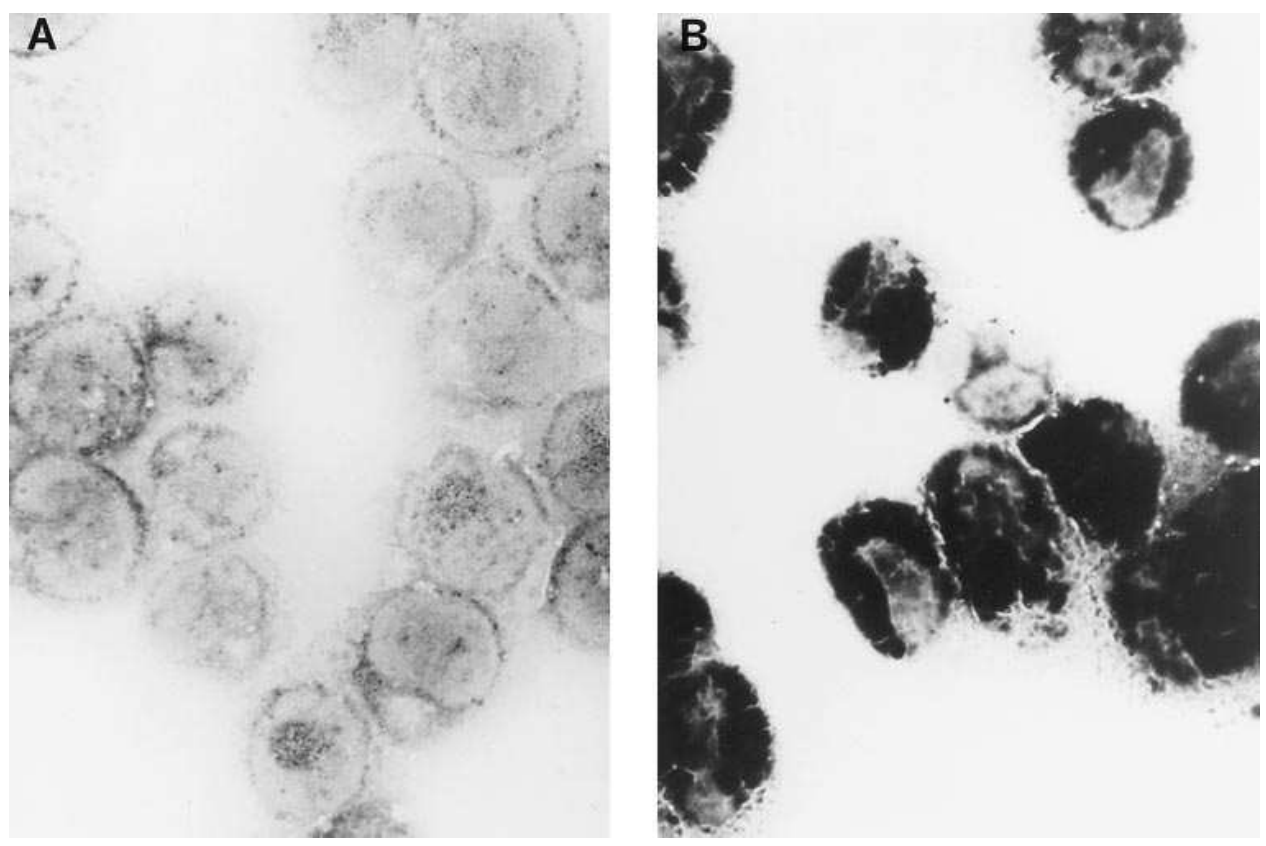

Figure 7. Expression of NSE (marker of monocytic differentiation) in NB4 cells. ( $A$ ) Untreated NB4 cells. (B) NB4 cells after culture with a combination of $\mathrm{KH} 1060$ and 9-cis-RA $\left(5 \times 10^{-7} \mathrm{M}, 3 \mathrm{~d}\right)$.
Inhibitory effects of the combination of KH 1060 and 9-cis-RA on clonal growth of NB4 cells were irreversible

The NB4 cells were cultured in liquid medium for $3 \mathrm{~d}$ with either KH 1060, 9-cis-RA $\left(10^{-11}-10^{-7} \mathrm{M}\right)$, or both (KH 1060 at $10^{-11}-10^{-7} \mathrm{M}$ and 9-cis-RA at $10^{-9} \mathrm{M}$ ), and washed extensively to remove the analogs before being plated in soft agar. Colonies were counted at day 10 of culture (Fig. 5). The NB4 cells pulsed for $3 \mathrm{~d}$ with 9-cis-RA $\left(10^{-11}-10^{-9} \mathrm{M}, 3 \mathrm{~d}\right)$ had an enhancement of their clonal proliferation; higher concentrations of 9-cis-RA $\left(10^{-8}-10^{-7} \mathrm{M}, 3 \mathrm{~d}\right)$ inhibited clonal growth of NB4 cells by $40-60 \%$ (Fig. 5). After pulse-exposure to KH 1060 $\left(10^{-8} \mathrm{M}, 3 \mathrm{~d}\right)$, clonal growth of NB4 cells was inhibited by $75 \%$ (Fig. 5). In contrast, when the cells were cultured in liquid culture with KH 1060 at either $10^{-11}, 10^{-10}$, or $10^{-9} \mathrm{M}$ plus 9-cisRA at $10^{-9} \mathrm{M}$ for $3 \mathrm{~d}$, thoroughly washed and plated in soft agar, colony number was reduced by more than $75,78 \%$, and $>99 \%(\mathrm{CI}<1)$, respectively (Fig. 5). These results suggest that the NB4 cells irreversibly lost the ability to form colonies after pulse exposure to the combination of both analogs. This could result from either death and/or irreversible differentiation of NB4 cells.

\section{Combination of both KH 1060 and 9-cis-RA induces differentiation of NB4 cells}

Functional assays. The NBT assay is a measurement of superoxide production and becomes positive as NB4 cells undergo either monocytic or granulocytic differentiation. A 3-d exposure of NB4 cells to either 9-cis-RA or KH $1060\left(10^{-6} \mathrm{M}\right)$ resulted in 30 and $<5 \%$ NBT-positive cells, respectively. The combination of both $\mathrm{KH} 1060$ and 9-cis-RA $\left(5 \times 10^{-7} \mathrm{M}\right)$

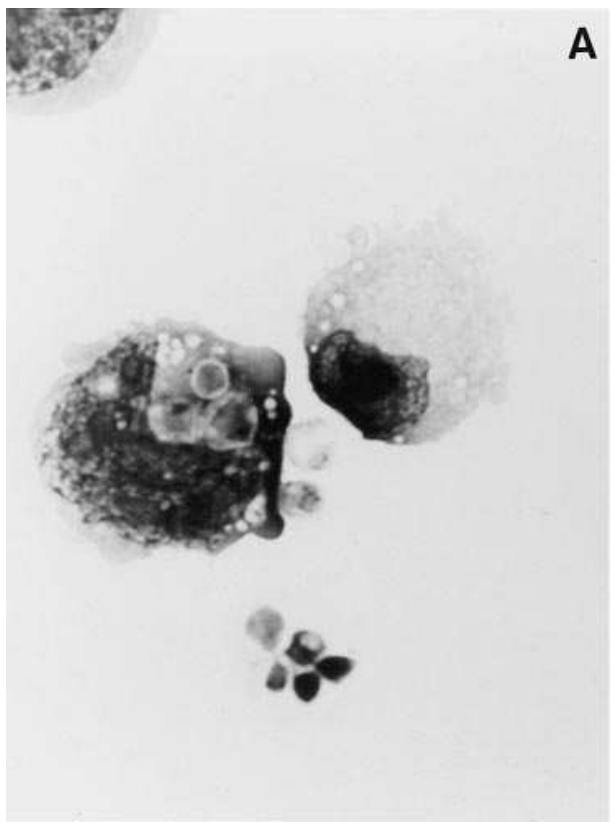

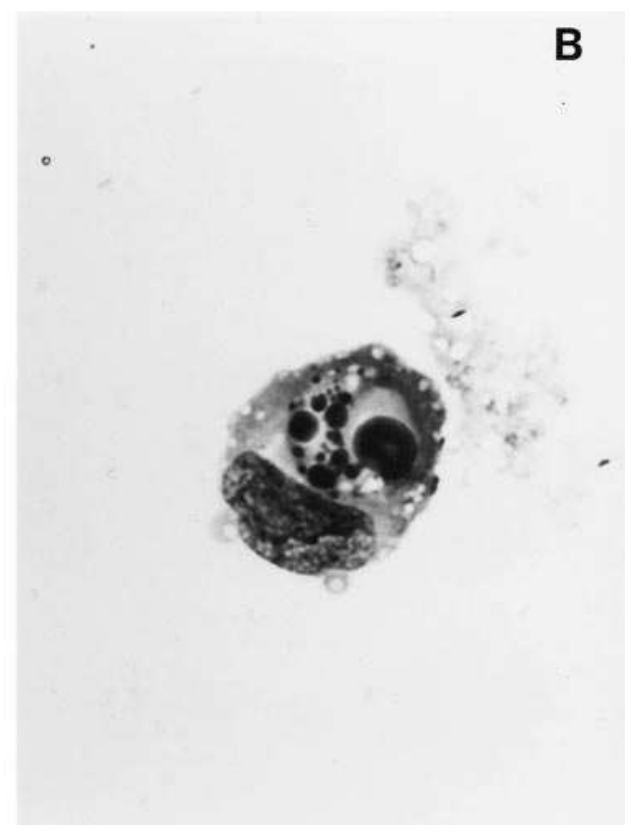

Figure 8. Ability of NB4 cells to phagocytize both $C$. albicans $(A)$ and an apoptotic NB4 cell $(B)$ after NB4 cells were incubated with a combination of KH 1060 and 9-cisRA $\left(5 \times 10^{-7} \mathrm{M}, 3 \mathrm{~d}\right)$. 

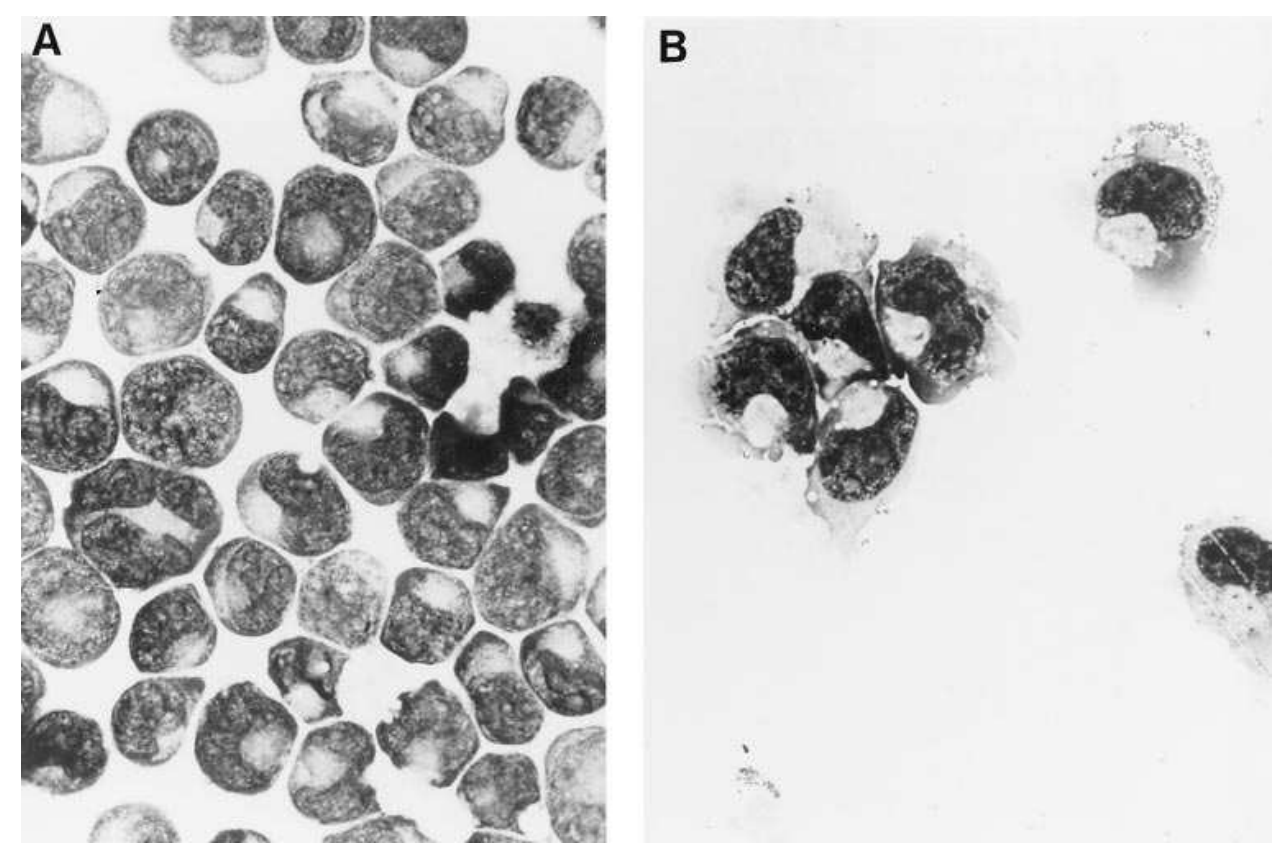

Figure 9. Morphology of NB4 cells before $(A)$ and after $(B)$ incubation with a combination of KH 1060 and 9-cis-RA $\left(5 \times 10^{-7} \mathrm{M}, 3 \mathrm{~d}\right)$.

acted synergistically $(\mathrm{CI}<1)$ by inducing $99 \%$ NBT-positive cells (Fig. 6).

The NSE is a monocytic-specific enzyme. About $10 \%$ of wild-type NB4 cells express weak NSE (fine granules) (Figs. 6 and $7 A$ ). No significant increase of this enzyme was observed after incubation with either 9-cis-RA $(16 \%)$ or KH 1060 $(18 \%)\left(10^{-6} \mathrm{M}, 3 \mathrm{~d}\right)$. However, the combination of both analogs $\left(5 \times 10^{-7} \mathrm{M}, 3 \mathrm{~d}\right)$ synergistically increased $(\mathrm{CI}<1)$ the percentage of NSE-positive NB4 cells to 80\% (Fig. 5), and those cells that were positive had prominent expression of the enzyme (Fig. 7 B).

Likewise, the ability to phagocytose $C$. albicans by NB4 cells increased significantly $(46 \%)$ after incubation with the combination of both analogs compared with either compound alone $(<10 \%)(P<0.001)$ (Fig. 6). Interestingly, the NBTand NSE-positivity, the ability to phagocytose $C$. albicans (Fig. $8 \mathrm{~A}$ ) and undergo apoptosis (Fig. $8 \mathrm{~B}$ ), which were observed after exposure of the NB4 cells to both analogs $\left(5 \times 10^{-7} \mathrm{M}\right.$, $3 \mathrm{~d}$ ), persisted even $2 \mathrm{~d}$ after washing the cells free of the combination of KH 1060 and 9-cis-RA (data not shown).

Morphology. Both untreated NB4 cells and those cultured for $3 \mathrm{~d}$ with either KH 1060 or 9-cis-RA $\left(10^{-6} \mathrm{M}, 3 \mathrm{~d}\right)$ continued to have predominantly the morphology of promyelocytic leukemia cells with large spherical nuclei surrounded by a thin shell of basophilic cytoplasm (Fig. $9 A$ ). In contrast, the cells cultured with both $\mathrm{KH} 1060$ and 9-cis-RA $\left(5 \times 10^{-7} \mathrm{M}, 3 \mathrm{~d}\right)$ developed condensed, lobulated nuclei characteristic of cells undergoing granulocyte-like differentiation (Fig. 9 B). Importantly, $\sim 85-90 \%$ of these cells became strongly adherent to the plastic culture dishes. In contrast, no adherence was observed after incubation with either KH 1060 or 9-cis-RA $\left(10^{-6} \mathrm{M}, 3 \mathrm{~d}\right.$, data not shown).

Myeloperoxidase is an enzyme synthesized at the promyelocytic stage of differentiation, which markedly decreases with myeloid maturation (45). Untreated NB4 cells expressed prominent levels of MPO protein on Western blot (Fig. 10). In sharp contrast, expression of the MPO protein decreased drastically during incubation of the cells with either KH 1060 or
9-cis-RA $\left(10^{-6} \mathrm{M}, 3 \mathrm{~d}\right)$, and expression was nearly undetectable after culture with both 9-cis-RA and KH $1060\left(10^{-6} \mathrm{M}, 3 \mathrm{~d}\right)$ (Fig. 10).

Analysis of cell membrane differentiation markers of NB4 cells Two-color flow analysis with mAbs anti-CD11b ( $\beta$-integrin subunit, expressed by both granulocytes and monocytes) and CD14 (late monocytic cell surface marker) showed that $<2 \%$ of untreated NB4 cells expressed CD14, and 12\% expressed CD11b (Fig. 11). The KH $1060\left(10^{-6}\right.$ M, 3 d) induced CD11b and CD14 expression $\left(57 \% \mathrm{CD} 11 \mathrm{~b}^{+} / \mathrm{CD}^{-} 4^{-}\right.$and $39 \% \mathrm{CD}^{-11 \mathrm{~b}^{+} /}$ CD14 ${ }^{+}$), but not CD11c ${ }^{+}$(a marker of granulocytic lineage). The 9-cis-RA alone $\left(10^{-6} \mathrm{M}, 3 \mathrm{~d}\right)$ induced high expression of the $\mathrm{CD} 11 \mathrm{~b}\left(70 \% \mathrm{CD} 11 \mathrm{~b}^{+} \mathrm{CD} 14^{-}\right)$and $\mathrm{CD} 11 \mathrm{c}^{+}(39 \%)$, but not $\mathrm{CD}_{14}{ }^{+}(<5 \%)$. The combination of both analogs $\left(5 \times 10^{-7} \mathrm{M}\right.$, $3 \mathrm{~d})$ resulted in a lower expression of $\mathrm{CD} 11 \mathrm{~b}^{+} / \mathrm{CD} 14^{-}(24 \%)$ than either 9-cis-RA (57\%) or KH 1060 (70\%) alone, but the combination synergistically $(\mathrm{CI}<1)$ increased the expression of $\mathrm{CD} 11 \mathrm{~b}^{+} / \mathrm{CD} 14^{+}(76 \%)$ and $\mathrm{CD} 11 \mathrm{c}^{+}(81 \%)$ compared with those cells exposed to either analog alone (Fig. 11). Also, only the combination of both analogs increased significantly the ex-

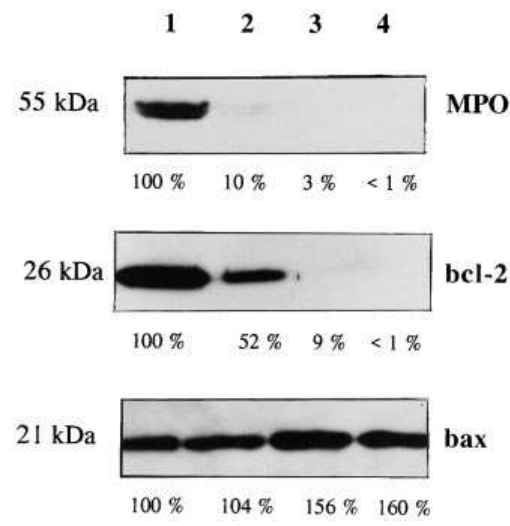

Figure 10. Expression of MPO, bcl-2, and bax proteins in NB4 cells measured by Western blot. Lane 1, control NB4 cells; lane 2, NB4 cultured with KH 1060 $\left(10^{-6} \mathrm{M}, 3 \mathrm{~d}\right)$; lane 3 , NB4 cultured with 9-cis-RA $\left(10^{-6} \mathrm{M}, 3 \mathrm{~d}\right)$; lane 4, NB4 cultured with the combination of KH 1060 and 9-cisRA $\left(5 \times 10^{-7} \mathrm{M}, 3 \mathrm{~d}\right)$. $30 \mu \mathrm{g}$ of protein was applied per lane. 


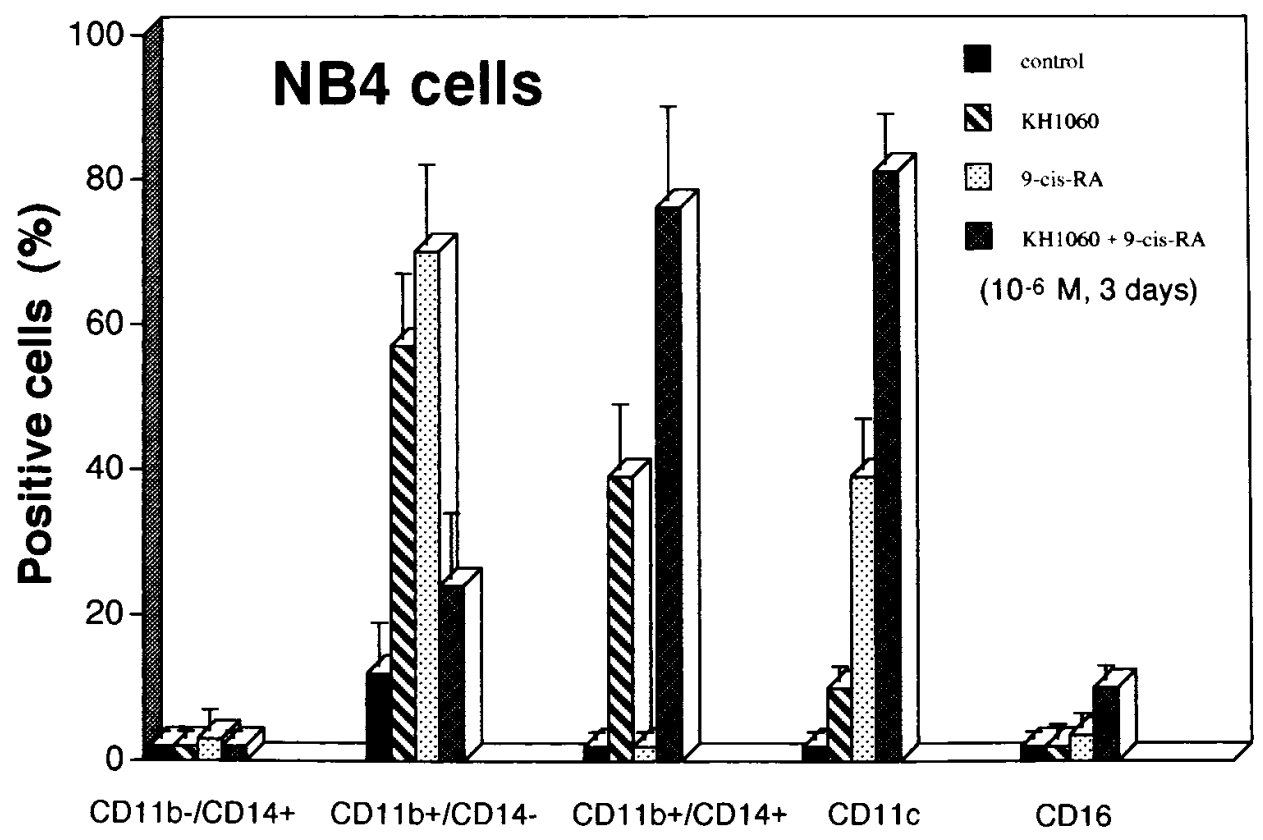

MoAbs
Figure 11. Induction of expression of cell surface antigens CD11b, CD14, CD11c, and CD16 on NB4 cells after culture with either $\mathrm{KH}$ $1060\left(10^{-6} \mathrm{M}, 3 \mathrm{~d}\right)$, 9-cis-RA $\left(10^{-6}\right.$, $3 \mathrm{~d})$ or both $\left(5 \times 10^{-7} \mathrm{M}, 3 \mathrm{~d}\right)$. Results represent mean \pm SD of three independent experiments as measured by one- or two-color direct immunofluorescence staining technique. pression of CD16, the marker of mature granulocytes, from $0.5 \%$ in control cells to $10 \%(P<0.01)$ (Fig. 11). To our knowledge, this is the first observation that this marker could be induced, albeit on a minority of leukemic cells, by mediators of differentiation.

The HLA-DR, a cell surface marker associated with myeloid differentiation (46), is not expressed on NB4 cells. Incubation of NB4 cells with either KH 1060 or 9-cis-RA alone $\left(10^{-6} \mathrm{M}\right.$, $3 \mathrm{~d})$ or with the combination of these analogs $\left(5 \times 10^{-7} \mathrm{M}, 3 \mathrm{~d}\right)$ did not induce expression of HLA-DR on NB4 cells (data not shown). Also, addition of IFN-gamma ( $5 \mathrm{~d}, 100 \mathrm{U} / \mathrm{ml})$ did not induce expression of HLA-DR (Fig. 12). Priming with 9-cisRA $\left(10^{-6} \mathrm{M}, 3 \mathrm{~d}\right)$, and then exposure to IFN-gamma ( $\mathrm{d}, 100$ $\mathrm{U} / \mathrm{ml}$ ) induced $12 \%$ of the cells to express HLA-DR ${ }^{+} / \mathrm{CD} 14^{+}$. Priming with both 9-cis-RA and KH $1060\left(5 \times 10^{-7} \mathrm{M}, 3 \mathrm{~d}\right)$, and then the addition of IFN-gamma $(2 \mathrm{~d}, 100 \mathrm{U} / \mathrm{ml})$ induced $40 \%$ of NB4 cells to express HLA-DR ${ }^{+} / \mathrm{CD} 14^{+}$(Fig. 12) with high mean fluorescence intensity on the positive cells (data not shown). All cells induced to express HLA-DR also expressed CD14, consistent with their macrophage-like differentiation (Fig. 12). The expression of CD69 (early marker for activated macrophages) was not observed (Fig. 12).

\section{Cell cycle analysis of NB4 cells}

Analysis of the cell cycle of NB4 cells after exposure to either KH 1060, 9-cis-RA $\left(10^{-6} \mathrm{M}, 3 \mathrm{~d}\right)$ or a combination of both ana$\operatorname{logs}\left(5 \times 10^{-7} \mathrm{M}, 3 \mathrm{~d}\right)$ is shown on Fig. $13.59 \%$ of the untreated cells were in $\mathrm{G} 0 / \mathrm{G} 1$ compared with 63,65 , and $80 \%$ of NB4 cells after culture with either KH 1060, 9-cis-RA, or both analogs, respectively (Fig. 13). Therefore, the combination of both analogs significantly increased the percentage of cells in G0/G1 compared with control cells $(P<0.05)$. The percentage of NB4 cells in S-phase decreased from 34\% (untreated control NB4 cells) to 30,23 , and $17 \%(P<0.05)$ for those cells cultured in the presence of either KH 1060, 9-cis-RA, or the combination of both compounds, respectively.

\section{Induction of apoptosis of NB4 cells}

The strong antiproliferative effect of the combination of $\mathrm{KH}$ 1060 and 9-cis-RA on NB4 cells in vitro may be caused in part by induction of apoptosis. As shown by analysis of cellular morphology (Fig. 14), apoptosis was induced in 8 and $28 \%$ of NB4 cells after their culture with either KH 1060 or 9-cis-RA $\left(10^{-6} \mathrm{M}, 3 \mathrm{~d}\right)$, respectively. Apoptosis only slightly increased to

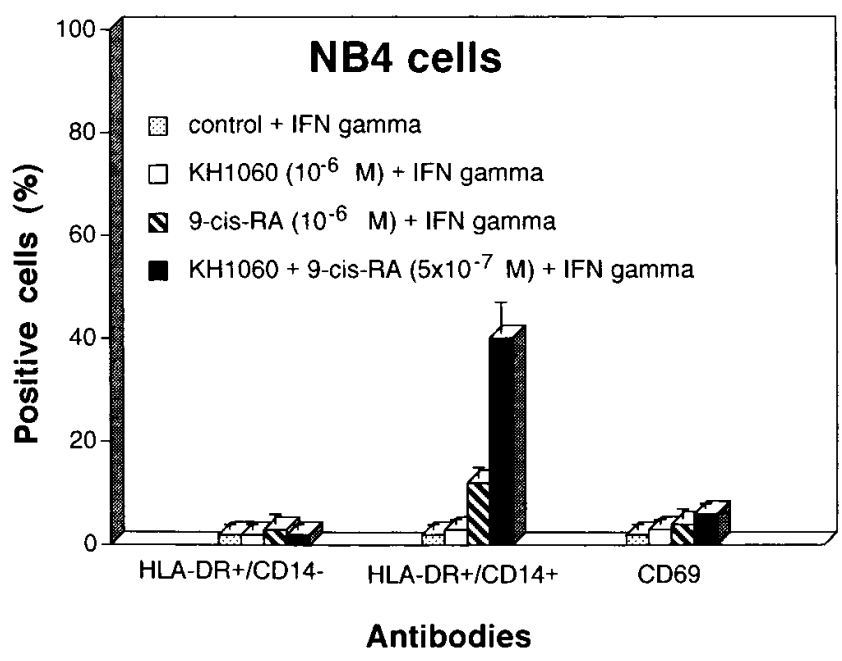

Figure 12. Effect of $\gamma$-IFN on induction of expression of cell surface antigens HLA-DR, CD14, or CD69 on NB4 cells after culture with either KH $1060\left(10^{-6} \mathrm{M}, 3 \mathrm{~d}\right), 9$-cis-RA $\left(10^{-6} \mathrm{M}, 3 \mathrm{~d}\right)$, or both $(5 \times$ $\left.10^{-7} \mathrm{M}, 3 \mathrm{~d}\right)$. Results represent mean $\pm \mathrm{SD}$ of two independent experiments as measured by one- or two-color direct immunofluorescence staining technique. Untreated NB4 cells had very low expression of either antigen. No increase in expression of HLA-DR occurred after NB4 cells were cultured with either KH $1060\left(10^{-6} \mathrm{M}, 3\right.$ d), 9-cis-RA $\left(10^{-6} \mathrm{M}, 3 \mathrm{~d}\right)$, or both $\left(5 \times 10^{-7} \mathrm{M}, 3 \mathrm{~d}\right)$ (data not shown). 


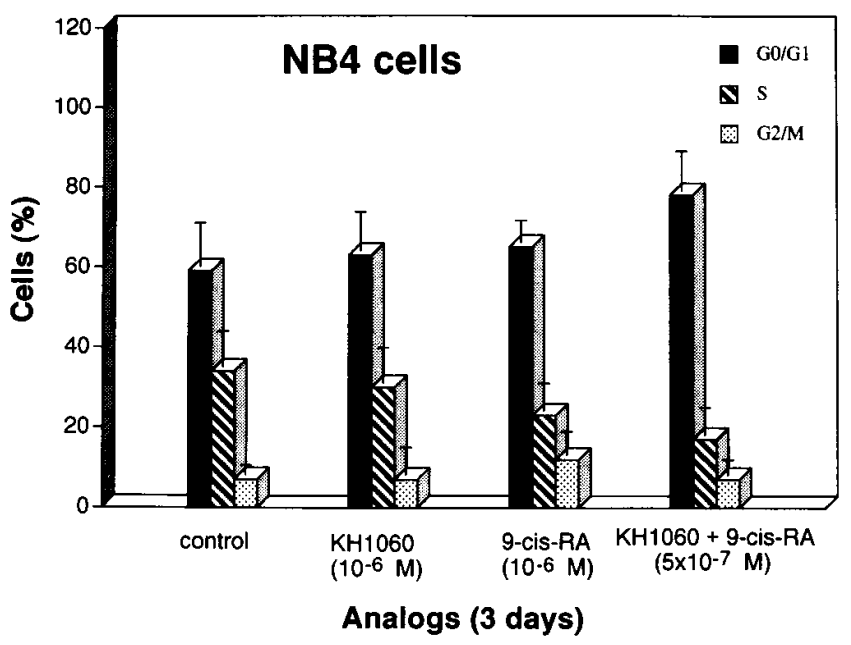

Figure 13. Cell cycle analysis of NB4 cells after culture with either KH $1060\left(10^{-6} \mathrm{M}, 3 \mathrm{~d}\right), 9-c i s-\mathrm{RA}\left(10^{-6} \mathrm{M}, 3 \mathrm{~d}\right)$, or both $\left(5 \times 10^{-7} \mathrm{M}\right.$, $3 \mathrm{~d})$. Results represent the mean $\pm \mathrm{SD}$ of four independent experiments.

$32 \%$ as measured by morphology (Fig. 14) when the cells were cultured with both KH 1060 and 9-cis-RA $\left(5 \times 10^{-7}\right.$ M, $\left.3 \mathrm{~d}\right)$. Apoptosis was confirmed by DNA fragmentation on ethidium bromide-stained agarose gels and by measurement of DNA nicks using Apop Tag Kit (Oncor Inc., Gaithersburg, MD) (data not shown).

Changes in expression of bax and bcl-2 after exposure of NB4 cells to the combination of KH 1060 and 9-cis-RA

Because 9-cis-RA alone or in combination with KH 1060 was able to induce apoptosis, we examined the effects of these analogs on the expression of apoptosis-related genes. Expression of bcl-2 protein, as analyzed by immunohistochemistry, was nearly $100 \%$ in untreated NB4 cells, and became almost undetectable $(<5 \%$ cells) when the cells were cultured with the combination of KH 1060 and 9-cis-RA $\left(5 \times 10^{-7} \mathrm{M}\right)$ for $3 \mathrm{~d}$ (Fig. 15). The cells with apoptotic bodies were almost always

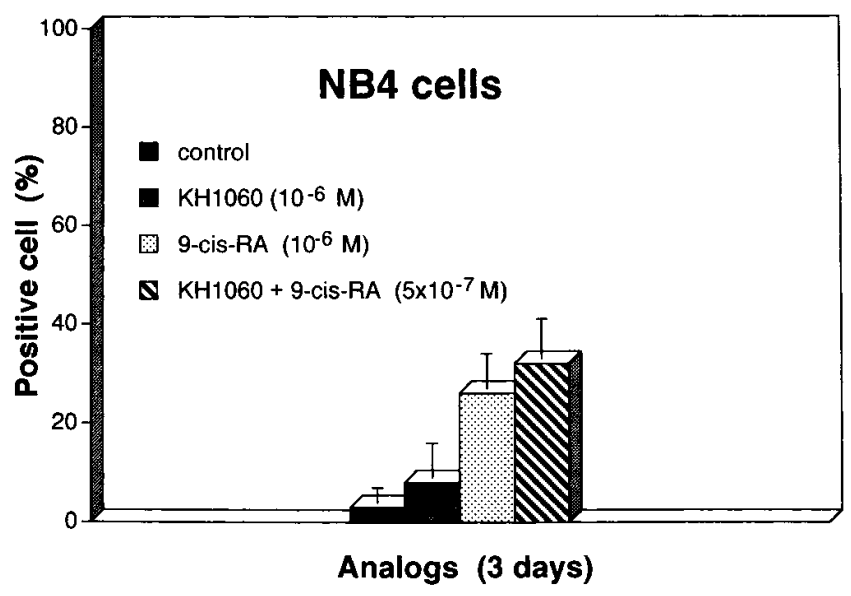

Figure 14. Apoptosis in NB4, as measured by morphology, after exposure for $3 \mathrm{~d}$ to either to KH $1060\left(10^{-6} \mathrm{M}\right)$, 9-cis-RA $\left(10^{-6} \mathrm{M}\right)$, or both $\left(5 \times 10^{-7} \mathrm{M}\right)$. Data are expressed as a percentage of apoptotic cells and represent the mean \pm SD of four experiments. Controls are untreated NB4 cells.

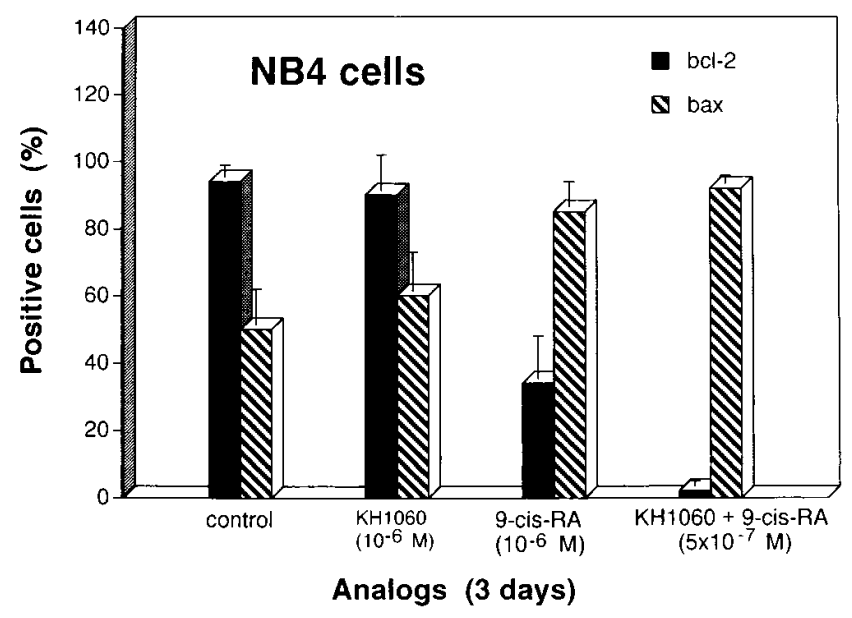

Figure 15. Expression of bcl-2 and bax in NB4 cells after their exposure for $3 \mathrm{~d}$ to either KH $1060\left(10^{-6} \mathrm{M}\right)$, 9-cis-RA $\left(10^{-6} \mathrm{M}\right)$, or both $\left(5 \times 10^{-7} \mathrm{M}\right)$. Data are expressed as a percentage of positive cells as measured by immunohistochemistry. Control cells are untreated NB4 cells. Results represent mean \pm SD of four or more independent experiments.

bcl-2 negative (data not shown). Exposure to either KH 1060 or 9-cis-RA $\left(10^{-6} \mathrm{M}\right)$ resulted in 90 and $34 \%$ of the cells expressing bcl-2, respectively.

The expression of bax in untreated NB4 cells as measured by immunohistochemistry was $\sim 50 \%$. The number of cells expressing bax protein increased significantly after incubation with 9-cis-RA alone $(85 \%, P<0.01)$, and the combination of KH 1060 plus 9-cis-RA (94\%) had little additional effect compared with 9-cis-RA alone (Fig. 15). These data were confirmed by Western blot analysis (Fig. 10) and by flow cytometry. Thus, after incubation of NB4 cells with KH 1060 alone, the number of bax-expressing cells (Fig. 16) was comparable to untreated cells (59 vs. 55\%), whereas 9-cis-RA alone, or combined with KH 1060, induced bax in almost all NB4 cells (94 and $96 \%$, respectively). Of note, the treatment of both analogs resulted in higher bax density than 9-cis-RA alone (2.4 vs. 1.4 relative fluorescence intensity index).

The effect of KH 1060, 9-cis-RA, and their combination on differentiation of fresh leukemic cells from an APL patient

The fresh APL cells from an untreated individual were unable to form colonies in the presence of either leukocytes condition medium (20\%), GM-CSF (Leukine, $20 \mathrm{ng} / \mathrm{ml}$; Immunex Corp., Seattle, WA), or PYXY321, a recombinant GM-CSF/IL-3 fusion protein $(20 \mathrm{ng} / \mathrm{ml}$, Immunex Corp.) (data not shown). The 9-cis-RA alone $\left(10^{-6} \mathrm{M}, 3 \mathrm{~d}\right)$ induced $\sim 21 \%$ of APL cells to differentiate to metamyelocytes and bands, and $45 \%$ became NBT-positive $(P<0.05)$. Interestingly, many of these mature forms still had Auer rods or bundles of Auer rods (data not shown). Exposure to the combination of both analogs $(5 \times$ $10^{-7} \mathrm{M}, 3 \mathrm{~d}$ ) synergistically increased differentiation compared with either 9-cis-RA or KH 1060 alone: $\sim 42 \%$ of the APL cells differentiated to metamyelocytes or bands, and $76-84 \%$ of the cells became NBT-positive $(P<0.05)$ (Table I). The $\mathrm{KH} 1060\left(10^{-6} \mathrm{M}\right)$ even after $5 \mathrm{~d}$, did not induce differentiation of APL blast cells.

The leukemic cells from the APL patient were induced to express CD11b by 9-cis-RA (49\%), but not by KH 1060; the combination of both did not increase expression of CD11b as 

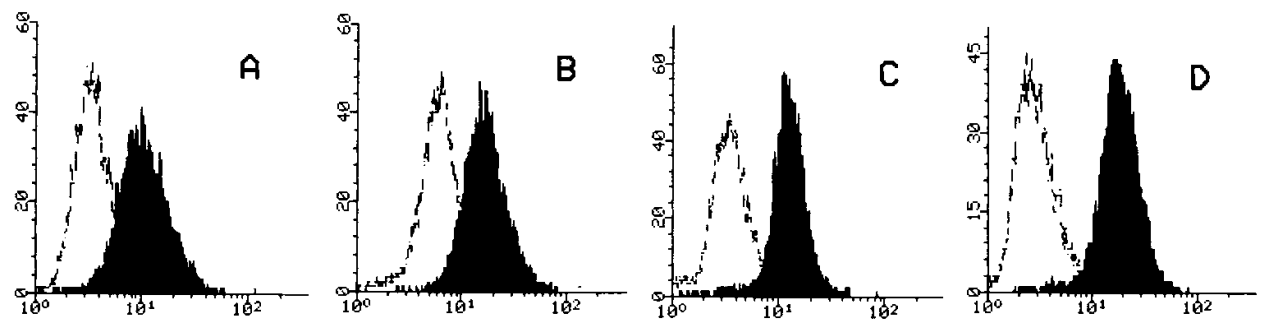

Figure 16. Expression of bax in NB4 cells, incubated for $3 \mathrm{~d}$ with medium $(A), \mathrm{KH} 1060\left(10^{-6} \mathrm{M}\right)$ (B), 9-cis-RA $\left(10^{-6} \mathrm{M}\right)(C)$, or both $\left(5 \times 10^{-7} \mathrm{M}\right)$. Cells were incubated with a rabbit polyclonal anti-human bax antibody (shaded area) or PBS (open area), followed by FITC-conjugated goat anti-rabbit IgG. The percentage of positive cells (ordinate) and relative intensity of fluorescence (abscissa) were calculated using the PCLYSIS II software.

compared with 9-cis-RA alone. In contrast with NB4 cells, fresh APL cells did not acquire macrophage-like characteristics after exposure to the analogs, as shown by their lack of expression of CD14 and NSE (Table I), as well as their lack of macrophagelike morphology (data not shown).

Most of the fresh APL cells (89-98\%) were in G0/G1 and did not undergo apoptosis (1-15\%) after $3 \mathrm{~d}$ of incubation with either 9-cis-RA, KH 1060, or both analogs (data not shown). The 9-cis-RA alone and in combination with KH 1060 strongly decreased the number of APL blasts that expressed bcl-2 protein, from $98 \%$ in control cultures to 10 and $8 \%$, respectively, as measured by immunohistochemistry (Table I). In contrast, the percentage of cells expressing bax as measured by immunohistochemistry increased from $26 \%$ in control cultures to $40 \%$ after exposure to 9 -cis-RA alone $(P<0.05)$. The combination of both KH 1060 and 9-cis-RA increased the bax positive cells from 26 to $59 \%$ and markedly increased the bax: bcl-2 ratio to 9.8 compared with 0.3 in control dishes (Table I).

\section{Discussion}

Hematopoiesis is regulated by a balance of cellular proliferation, differentiation, and apoptosis. Imbalances of regulation may lead to inappropriate growth of the cells. APL is characterized by a block in differentiation of the leukemic cells at an immature, proliferating stage of development $(47,48)$. Treatment options, therefore, include not only new cytostatic drugs but also differentiation- and apoptosis-inducing agents.

Our data showed that the 20-epi vitamin $\mathrm{D}_{3}$ analogs $(\mathrm{KH}$ 1060, CB1093, KH1266) are powerful inhibitors of clonal growth of NB4 cells; in contrast, 1,25D had either little or no effect on inhibition of clonal proliferation of these leukemic cells. The mechanism mediating these effects is unclear. The 20-epi family of vitamin $\mathrm{D}_{3}$ analogs (Fig. 1) differs markedly from 1,25D in their conformational distribution (49). The side chain of these analogs is directed to the left, while it is directed to the right in the "normal" isomers. This can induce significant change in the conformation of the vitamin $\mathrm{D}_{3}$ receptor upon binding to the ligand, and thereby produce differences in the biological selectivities of these compounds. The HL-60 and U937 cells do not contain a PML-RAR $\alpha$ fusion protein, but do express normal RARs and RXRs $(50,51)$, and both are inhibited in their clonal proliferation by $1,25 \mathrm{D}$. In contrast, the PML-RAR $\alpha$ fusion protein, which is present in NB4 cells, can heterodimerize with RXR and prevent RXR from going to its normal nuclear localization (52). The sequestration of RXR by PML-RAR $\alpha$ is reversed when the cells are treated with ATRA, resulting in RXR returning to a diffuse nuclear pattern (53). The interaction of PML-RAR $\alpha$ with RXR may interfere with other nuclear receptor pathways that involve RXR. One study suggested that, by competing for RXR, PMLRAR $\alpha$ can inactivate the vitamin $\mathrm{D}_{3}$ receptor (54). The 20-epi analogs can efficiently enhance homo- and heterodimerization of VDR with VDR and RXR as compared with 1,25D, which predominately forms VDR/RXR heterodimers $(17,55,56)$. The competition between the RAR and VDR for association with RXR may provide an additionally important control step for these ligands (18).

The retinoids (9-cis-RA and ATRA) were not as potent as KH 1060 and CB1093 in inhibiting clonal proliferation of NB4 cells $\left(\mathrm{ED}_{50}, 10^{-9} \mathrm{M}\right)$, and the SR11236 (RXR $\alpha$-specific analog) and SR11238 (anti-AP analog) showed no inhibitory activity on clonal growth of NB4 cells. The data with SR11236 paralleled our previous data (57), which showed no inhibition of clonal proliferation of HL-60 myeloid leukemic cells with another RXR $\alpha$-specific analog (SR11217). Also, we have observed that an anti-AP analog (SR11238) was unable to inhibit the clonal growth of HL-60 cells (58). Therefore, retinoids that

Table I. Effect of 9-cis-RA and/or KH 1060 on Fresh APL Blast Cells

\begin{tabular}{|c|c|c|c|c|c|c|c|}
\hline & Cell number & Blasts & $\begin{array}{l}\text { Metamyelocytes } \\
\text { and older }\end{array}$ & $\begin{array}{l}\mathrm{NBT} / \mathrm{NSE} \\
\text { positive cells }\end{array}$ & CD11b/CD14 & Bax/bcl-2 & $\begin{array}{c}\text { Bax:bcl-2 } \\
\text { ratio }\end{array}$ \\
\hline & $\left(\times 10^{6}\right)$ & $(\%)$ & $(\%)$ & $(\%)$ & $(\%)$ & $(\%)$ & \\
\hline Control cells & 2.6 & 98 & $<1$ & $2 /<1$ & $2 / 1$ & $26 / 98$ & 0.3 \\
\hline 9-cis-RA & 1.4 & 52 & 21 & $45 /<1$ & $49 / 1$ & $46 / 10$ & 4.6 \\
\hline KH 1060 & 1.8 & 98 & $<1$ & $2 /<1$ & $3 /<1$ & $25 / 78$ & 0.3 \\
\hline 9-cis-RA + KH 1060 & 0.9 & 16 & 42 & $76 /<1$ & $52 /<1$ & $59 / 6$ & 9.8 \\
\hline
\end{tabular}

The fresh APL blast cells were cultured with either 9-cis-RA, KH $1060\left(10^{-6} \mathrm{M}, 3 \mathrm{~d}\right)$, or both $\left(5 \times 10^{-7} \mathrm{M}, 3 \mathrm{~d}\right)$. Cells were harvested and analyzed. 
are either RXR- or anti-AP-1-selective probably have little role in either normal or abnormal hematopoiesis. In contrast, these analogs do have antiproliferative activities in solid tumors including prostate and cervical cancer cells $(59,59 a)$.

The combination of KH 1060 and 9-cis-RA synergistically enhanced the inhibition of clonal growth of NB4 cells, and this inhibition was irreversible. This combination of analogs arrested the NB4 cells in G0/G1 of the cell cycle. The combination of CB1093 and 9-cis-RA had a similar effect on inhibition of clonal proliferation and G0/G1 cell cycle arrest of the NB4 cells (data not shown).

Our differentiation data indicated that neither 9-cis-RA nor KH 1060 ( $10^{-6}$ M, 3 d) separately were strong inducers of differentiation of NB4 cells as measured by NBT, NSE, expression of surface antigen markers of differentiation, and morphological criteria. Examination of levels of the MPO protein gave a different result. The MPO gene is expressed at the promyelocyte stage of differentiation and transcription of the protein ceases during further monocytic and granulocytic differentiation. The MPO protein is strongly expressed in NB4 cells, and levels rapidly decreased after incubation with either 9-cis-RA or the combination of both 9-cis-RA and KH 1060 as measured by Western blot. Surprisingly, exposure of the cells to KH 1060, which did not have a marked effect on other parameters of differentiation, did prominently decrease levels of MPO (90\% decrease). These data suggest that the suppression of expression of this azurophilic (primary) granule protein is under a different pathway of control than are the other markers of differentiation.

When NB4 cells were exposed to both KH 1060 and 9-cisRA, they functionally differentiated to phagocytic cells engulfing both yeast and apoptotic cells. Interestingly, they displayed a neutrophil-like morphology, while exhibiting several properties specific to monocytic cells; e.g., high level of expression of CD14 and prominent display of monocytic-specific esterase activity. In contrast, HL-60 myeloblasts could not be induced to express NSE protein after their exposure to a combination of both KH 1060 and 9-cis-RA (25).

The analysis of cell surface markers by two-color flow detected the increase of expression of CD11b+/CD14+, CD11c, and CD16 in NB4 cells after their incubation with the combination of both KH 1060 and 9-cis-RA. We believe that this is the first observation of a significant increase of CD16, a marker of late myeloid differentiation, after treatment of the leukemic cells by modifiers of differentiation. Neither $\mathrm{KH}$ 1060 nor 9-cis-RA alone (our data), nor ATRA and/or G-CSF (60) were able to induce the upregulation of expression of this protein on NB4 cells. Furthermore, CD16 was not expressed on HL-60 cells even after $14 \mathrm{~d}$ of incubation with 1,25D (61). Expression of the cell surface antigens CD11b, CD11c, and CD14 occurs gradually during the normal development of mature monocytes from hematopoietic stem cells $(62,63)$. CD14 is the receptor for the complex of LPS and LPS binding protein (64), and is perhaps one of the most specific monocytic cell surface antigens (62). The expression of CD14 was significantly increased after incubation with KH 1060 and increased even more by the combination of KH 1060 and 9-cis-RA. Expression of this molecule was always coupled with CD11b expression. The 9-cis-RA had negligible effects on expression of CD14 on NB4 cells.

CD11b and CD11c are both members of the $\beta_{2}$ integrin family of leukocyte adhesion molecules (65). Interestingly, al- though exposure to KH 1060 promotes CD11b expression and 9-cis-RA increases expression of both CD11b and CD11c, only the combination of both analogs was able to cause most $(\sim 90 \%)$ of the NB4 cells to become strongly adherent to the bottom of plastic culture dishes.

HLA-DR is a cell surface marker expressed on monocytes and macrophages and is rarely expressed on myeloid leukemia cell lines, including the NB4 cells. Exposure to $\gamma$-IFN increased the expression of HLA-DR antigens on several other myeloid leukemic cell lines, and 1,25D potentiated this effect $(46,66)$. As shown by our data, $\gamma$-IFN did not affect the expression of HLA-DR on NB4 cells. Likewise, neither KH 1060 nor 9-cis-RA alone was able to induce the expression of HLADR antigens on this cell line. Previous studies also showed that ATRA did not induce expression of HLA-DR on NB4 cells (100 nM, 2 d) (67). We have found that $\gamma$-INF was able to induce significantly the expression of HLA-DR on NB4 cells only after priming them with a combination of KH 1060 and 9-cis-RA. The two-color flow analysis with CD14 and HLA-DR indicated that HLA-DR expression was always coupled with CD14 positivity. These cells, however, did not express CD69, an early marker of activated macrophages.

Taken together, as shown by our data and those from other groups, both $\mathrm{KH} 1060$ and retinoic acid alone $(60,68,69)$ were able to promote only the early steps of maturation of APL cell lines. This differentiation, however, was either limited or defective and reversible (data not shown). As demonstrated by our data, only the combination of both analogs (KH 1060 and 9-cis-RA) induced irreversible differentiation of NB4 cells to functionally active cells of a mixed granulocytic-monocytic lineage that were arrested in G0/G1. The other 20-epi analogs, either CB1093 or KH1266, in combination with 9-cis-RA, had a similar potency as KH 1060 in the induction of differentiation of NB4 cells (data not shown).

Our data of differentiation in vitro with fresh leukemic cells from a patient with APL at the time of diagnosis indicated that these cells were more sensitive to induction of differentiation by 9-cis-RA, as measured by morphology (Table I), as compared with the NB4 cell line that was established from a relapsed APL patient after recieving ATRA therapy (34). However, differentiation of these APL cells was still reversible (data not shown). The combination of both KH 1060 and 9-cisRA resulted in a synergistic, irreversible induction of differentiation of APL cells towards neutrophils without evidence of monocytic differentiation (Table I).

To gain insight into the remarkable antileukemic effects of the combination of KH 1060 and 9-cis-RA, apoptosis and expression of the apoptosis-related proteins (bcl-2 and bax) were examined in the NB4 cells. Apoptosis is an active process that contributes to the shaping of organs during embryogenesis, to the maintenance, growth, or involution of tissues, and to the elimination of damaged cells. Dysregulation of this process can contribute to cancer. Our data showed that 9-cis-RA significantly increased the number of apoptotic NB4 cells $(28 \%)$ compared with control, untreated NB4 cells. The combination of 9-cis-RA and KH 1060 did not significantly induce more apoptotsis compared with 9-cis-RA alone.

The apoptosis-related protein bcl-2, which promotes cell survival, is overexpressed in many types of human tumors. This protein is induced by a wide variety of stimuli, including chemotherapeutic drugs and gamma irradiation $(8,10,70,71)$. Exposure of NB4 cells to KH 1060 alone did not change the 
percentage of cells expressing bcl-2, as measured by immunohistochemistry (Fig. 15), but did decrease the protein level of bcl-2 by $\sim 50 \%$ as measured by Western blot (Fig. 10). The 9-cis-RA alone dramatically decreased levels of expression of bcl-2 by the two assays. The combination of both compounds resulted in negligible expression of bcl-2 protein (Figs. 10 and 15).

The product of the bax gene promotes, rather than blocks, cell death (10). It has $\sim 20 \%$ homology to the bcl- 2 protein, forms heterodimers with bcl-2, and abrogates the latter's ability to suppress apoptosis. Thus, the ratio of bcl-2 to bax often helps to determine cell survival after an apoptotic stimulus (10). The bax protein is expressed in $\sim 50 \%$ of NB4 cells. After incubation with 9-cis-RA, we observed an increased expression of bax protein; however, KH 1060 had little effect on the level of bax expression (Figs. 10 and 15). The combination of both KH 1060 and 9-cis-RA did not change significantly the expression of this protein, as compared with 9-cis-RA alone (Figs. 10 and 15). Taken together, the results suggest that the increased level of bax more closely correlated with the induction of apoptosis than did either the level of bcl-2 or the ratio of bcl-2/bax in the NB4 cells. As compared with 9-cis-RA, the combination of KH 1060 and 9-cis-RA resulted in a greater decrease in bcl-2 and increase in the bcl2/bax ratio, but as compared with 9-cis-RA, the combination did not result in a significant increase in apoptosis of NB4.

The incubation of the fresh APL cells with 9-cis-RA alone significantly decreased the number of bcl-2 positive cells $(P<$ $0.001)$ and increased the number of bax positive cells $(P<$ $0.05)$ and the bax:bcl-2 ratio $(P<0.01)$ compared with control; however, only $11 \%$ of blasts underwent apoptosis after $3 \mathrm{~d}$ of treatment, as measured by morphology, and DNA nicks using the ApopTag Kit (data not shown). The combination of both 9-cis-RA and KH 1060 did not significantly increase the percentage of apoptotic cells, even though the bax:bcl-2 ratio was about two times higher in the APL cells as compared with those cultured with 9-cis-RA (Table I). Our explanation for this disparity in levels of apoptotic-related proteins and apoptosis is that the main effect of both analogs on APL cells is the induction of irreversible differentiation to functionally active cells. Mature granulocytes represent the most abundant and shortest lived of all the hematopoietic cell populations, and apoptosis appears to be an essential component of terminal differentiation for aging neutrophils (72). The period of cultivation in our experiment $(3 \mathrm{~d})$ was too short for the promyelocytic leukemic cells to terminally differentiate and undergo apoptosis. In fact, after $5 \mathrm{~d}$ of cultivation of fresh APL cells with a combination of both analogs, almost all cells underwent apoptosis, as measured by morphology.

Taken together, our data demonstrate that the combination of a 20-epi vitamin $\mathrm{D}_{3}$ analog with 9-cis-RA is a powerful inhibitor of proliferation and a strong inducer of irreversible differentiation of APL cells. The combination of these secosteroids may provide an alternative approach to therapy of APL and may be effective in other types of tumors.

\section{Acknowledgments}

We thank Dr. Peter Shintaku for help with the immunochemistry, Dr. Adrian Gombert and Dr. David Flevr for their technical help in Western blot analysis. We thank Maureen Kinney, Mareile Campbell, and Gail Jao for their excellent secretarial assistance, and Patricia Lin from the Flow Cytometry Core Facility (Cedars-Sinai Medical Center) for her generous technical assistance.

This study was supported by National Institutes of Health grants CA-42710 and CA-43277, the Parker-Hughes Trust, Concern Foundation, and the Tom Collier Research Fund. E. Elstner is supported in part by a grant from the Deutsche Forschunsgemeinschaft (DFG). H.P. Koeffler is a member of the Jonsson Comprehensive Cancer Center and holds the Mark Goodson Chair of Oncology Research.

\section{References}

1. Warrell, R.P., Jr. 1993. Retinoid resistance in acute promyelocytic leukemia: new mechanisms, strategies, and implications. Blood. 82:1949-1953.

2. Raza, A., Y. Maheshwari, and H.D. Preisler. 1987. Differences in cell cycle characteristics among patients with nonlymphocytic leukemia. Blood. 69: 1637-1653.

3. Raza, A., N. Yousuf, A. Abbas, A. Umerani, A. Mehdi, S.A.J. Bokhari, Y. Sheikh, K. Qadir, J. Freeman, M. Masterson, et al. 1992. High expression of transforming growth factor $\beta$, long cycle times and a unique clustering of S-phase cells in patients with acute promyelocitic leukemia. Blood. 79:1037-1048.

4. Grignani, F., P.F. Ferrucci, U. Testa, G. Talamo, M. Fagioli, M. Alcalay, A. Mencarelli, F. Grignani, C. Peschle, I Nicoletti, and P.G. Pelicci. 1993. The expression of the PML/RAR $\alpha$ protein in U937 blocks vit $\mathrm{D}_{3}$-induced differentiation and increases proliferation and survival of cells in low serum concentration. Cell. 74:423-431.

5. Fagioli, M., F. Grignani, P.F. Ferrucci, M. Alcallay, A. Mencarelli, I. Nicoletti, and G. Pelicci. 1994. Effect of the acute promyelocytic leukemia $\mathrm{PML} / \mathrm{RAR} \alpha$ protein on differentiation and survival of myeloid precursors. Leukemia (Baltimore). 8(Suppl. 1):S7-11.

6. Marx, J. 1993. Cell death studies yield cancer clues. Science (Wash. DC). 259:760-761.

7. Wyllie, A.H., J.F.R. Kerr, and A.R. Currie. 1980. Cell death: the significance of apoptosis. Int. Rev. Cytol. 68:251-306.

8. Hockenbery, D., G. Nufiez, C. Milliman, R.D. Schreiber, and S.J. Korsmeyer. 1990. Bcl-2 is an inner mitochondrial membrane protein that blocks programmed cell death. Nature (Lond.). 348:334-339.

9. Vaux, D.L., S. Cory, and J.M. Adams. 1988. Bcl-2 gene promotes haemopoietic cell survival and cooperates with c-myc to immortalize pre-B-cells. Nature (Lond.). 335:440-446.

10. Oltvai, Z., C. Milliman, and S.J. Korsmeyer. 1993. Bcl-2 heterodimerizes in vivo with a conserved homolog, Bax that accelerates programmed cell death. Cell. 74:609-619.

11. Heyman, R., D. Mangelsdorf, J. Dyck, R.B. Stein, G. Eichele, and R.M. Evans. 1992. 9-cis retinoic acid is a high affinity ligand for the retinoid X receptor. Cell. 68:397-406.

12. Levin, A., L. Strzenbecker, S. Kazmer, T. Bosakowski, C. Huselton, G. Allenby, J. Speck, C. Kratzeisen, M. Rosenberger, A. Lovey, and J.F. Grippo. 1992. 9-cis retinoic acid stereoisomer binds and activates the nuclear receptor RXR- $\alpha$. Nature (Lond.). 335:359-361.

13. Kizaki, M., Y. Ikeda, R. Tanosaki, H. Nikajama, M. Morikawa, A. Sakashita, and H.P. Koeffler. 1993. Effects of novel retinoic acid compound, 9-cis-retinoic acid, on proliferation, differentiation and expression of retinoic acid receptor RNA by HL-60 cells. Blood. 83:3592-3599.

14. Sakashita, A., M. Kizaki, S. Pakkala, G. Schiller, N. Tsuroka, R. Tomosaki, J.F. Cameron, M.I. Dawson, and H.P. Koeffler. 1993. 9-cis-retinoic acid: effects on normal and leukemic hematopoiesis in vitro. Blood. 81:1009-1016.

15. Miller, W.H., Jr., A. Jakubowski, W.P. Tong, V.A. Miller, J.R. Rigas, F. Benedetti, G.M. Gill, J.A. Truglia, E. Ulm, M. Shirley, and R.P. Warrell, Jr. 1995. 9-cis retinoic acid induces complete remission but does not reverse clinically acquired retinoid resistance in acute promyelocytic leukemia. Blood. 85: 3021-3027.

16. Baker, A.R., D.P. McDonnell, M. Hughes, T.M. Crisp, D.J. Mangelsdorf, M.R. Haussler, J.W. Pike, J. Shine, and B.W. O'Malley. 1988. Cloning and expression of full-length cDNA encoding human vitamin D receptor. Proc. Natl. Acad. Sci. USA. 85:3294-3298.

17. Imai, Y., J.W. Pike, and H.P. Koeffler. 1995. Potent vitamin $\mathrm{D}_{3}$ analogs: their abilities to enhance transactivation and to bind the vitamin $D_{3}$ response element. Leuk. Res. 19:147-158.

18. Carlberg, C., I. Bendik, A. Wyss, E. Meier, L.J. Sturzenbecker, J.F Grippo, and W. Hunziker. 1993. Two nuclear signaling pathways for vitamin D. Nature (Lond.). 361:657-660.

19. Schräder, M., I. Bendik, M. Becker-André, and C. Carlberg. 1993. Interaction between retinoic acid and vitamin D signaling pathways. J. Biol. Chem. 268:17830-17836.

20. Schräder, M., K.M. Müller, and C. Carlberg. 1994. Specificity and flexibility of vitamin D signaling. J. Biol. Chem. 269:5501-5505.

21. Koeffler, H.P., K. Hirji, and L. Itri. Southern California Leukemic Group. 1985. 1,25-dhydroxyvitamin $\mathrm{D}_{3}$ : in vivo and in vitro effects on human preleukemic and leukemic cells. Cancer Treat. Rep. 69:1399-1407. 
22. Bar-Shavit, Z., A.J. Kahn, K.R. Stone, J. Trial, T. Hilliard, P. Reitsma, and S.L. Teitelbaum. 1986. Reversibility of vitamin D-induced human leukemia cell maturation. Endocrinology. 118:679-686.

23. Studzinski, G.P., and Z.S. Brelvi. 1987. Changes in proto-oncogene expression associated with reversal of macrophage-like differentiation of HL-60 cells. J. Natl. Cancer Inst. (Bethesda). 79:67-76.

24. Binderup, L., S. Latini, E. Binderup, C. Bretting, M. Calverley, and K. Hansen. 1991. 20-epi-vitamin $\mathrm{D}_{3}$ analogues: a novel class of potent regulators of cell growth and immune responses. Biochem. Pharmac. 42:1569-1575.

25. Elstner, E., Y.Y. Lee, M. Hashiya, S. Pakkala, L. Binderup, A.W. Norman, W.H. Okamura, and H.P. Koeffler. 1994. 1 $\alpha$,25-dihydroxy-20-epi-vitamin $\mathrm{D}_{3}$ : an extraordinarily potent inhibitor of leukemic cell growth in vitro. Blood. 84:1960-1968.

26. Elstner, E., M. Linker-Israeli, J. Le, I. Griller, J. Said, P. Shintaku, S. Krajewski, J.C. Reed, L. Binderup, and H.P. Koeffler. 1996. Combination of potent 20-epi-vitamin $\mathrm{D}_{3}$ analog (KH 1060) and 9-cis-retinoic acid inhibits irreversibly clonal growth, decreases bcl-2 expression and induces apoptosis in HL-60 leukemic cells. Cancer Res. 56:3570-3576.

27. Elstner, E., M. Linker-Israeli, J. Said, T. Umiel, S. de Vos, I.P. Shintaku, D. Heber, L. Binderup, M. Uskokovic, and H.P. Koeffler. 1995. 20-epi-vitamin $\mathrm{D}_{3}$ analogs: a novel class of potent inhibitors of proliferation and inducers of differentiation of human breast cancer cell lines. Cancer Res. 55:2822-2830.

28. Elstner, E., J. Le, T. Umiel, J. Said, S. Krajewski, J.C. Reed, L. Binderup, and H.P. Koeffler. 1996. Novel 20-epi-vitamin $\mathrm{D}_{3}$ analogs potently affect prostate cancer cells. Proc. Am. Assoc. Cancer Res. 37:387. (Abstr. 2640).

29. de Vos, S., S. Holden, D. Heber, E. Elstner, L. Binderup, M. Uskokovic, B. Rude, D.L. Chen, S.K. Cho, and H.P. Koeffler. 1996. In vitro effects of potent vitamin $\mathrm{D}_{3}$ analogs on clonal proliferation of human prostate cancer cell lines. Prostate. In press.

30. Lennon, S.V., S.J. Martin, and T.G. Cotter. 1991. Dose-dependent induction of apoptosis in human tumor cell lines by widely diverging stimuli. Cell Prolif. 24:203-214

31. Martin, S.J., and D.R. Green. 1994. Apoptosis as a goal of cancer therapy. Curr. Opin. Oncol. 6:616-621.

32. Nagy, L., V. Thomázy, P. Syka, R. Heyman, R. Chandraratna, and P. Davies. 1995. Activation of retinoid X receptors induces apoptosis in HL-60 cell lines. Mol. Cell. Biol. 15:3540-3551.

33. Mehta, K., T. McQueen, N. Neamati, S. Collins, and M. Andreeff. 1996. Activation of retinoid receptors RAR $\alpha$ and $\mathrm{RXR} \alpha$ induces differentiation and apoptosis, respectively, in HL-60 cells. Cell Growth Differ. 7:179-186.

34. Lanotte, M., V. Martin-Thouvenin, S. Najman, P. Ballerini, F. Valensi, and R. Berger. 1991. NB4, a maturation inducible cell line with $\mathrm{t}(15,17)$ marker isolated from a human acute promyelocytic leukemia (M3). Blood. 77:10801086.

35. Collins, S.J., F.W. Ruscetti, R.E. Gallagher, and R.C. Gallo. 1979. Normal functional characteristics of cultured human promyelocytic leukemia cells (HL-60) after induction of differentiation by dimethylsulfoxide. J. Exp. Med. 149:969-974.

36. Munker, R., A.W. Norman, and H.P. Koeffler. 1986. Vitamin D compounds. Effects on clonal proliferation and differentiation of human myeloid cells. J. Clin. Invest. 87:424-430.

37. Sellins, K.S., and J.J. Cohen. 1987. Gene induction by gamma-irradiation leads to DNA fragmentation in lymphocytes. J. Immunology. 139:3199-3206.

38. Krajewski, S., C. Blomqvist, K. Franssila, M. Krajewska, V.M. Wasenius, E. Niskanen, S. Nordling, and J.C. Reed. 1995. Reduced expression of proapoptotic gene BAX is associated with poor response rates to combination chemotherapy and shorter survival in women with metastatic breast adenocarcinoma. Cancer Res. 55:4471-4478.

39. Delia, D., A. Aiello, D. Soligo, E. Fontanella, C. Melani, F. Pezzella, M.A. Pierotti, and G.D. Pota. 1992. bcl-2 proto-oncogene expression in normal and neoplastic human myeloid cells. Blood. 79:1291-1298.

40. Lagasse, E., and I.L. Weissman. 1994. bcl-2 inhibits apoptosis of neutrophils but not their engulfment by macrophages. J. Exp. Med. 179:1047-1052.

41. Selsted, M.E., C.W. Miller, M.J. Novotny, W.L. Morris, and H.P. Koeffler. 1993. Molecular analysis of myeloperoxidase deficiency shows heterogeneous patterns of the complete deficiency state manifested at the genomic, mRNA, and protein level. Blood. 82:1317-1322.

42. Territo, M.C., and M.J. Cline. 1977. Monocyte function in man. J. Immunol. 118:187-192.

43. Berenbaum, M.C. 1989. What is synergy? Pharmacol. Rev. 41:93-141.

44. Chen, Z.X., and T.R. Breitman. 1994. Tributyrin: a prodrug of butyric acid for potential clinical application in differentiation therapy. Cancer Res. 54: 3494-3499.

45. Lübbert, M., F. Herrmann, and H.P. Koeffler. 1991. Expression and regulation of myeloid-specific genes in normal and leukemic myeloid cells. Blood. 77:909-924.

46. Koeffler, H.P., J. Ranyard, L. Yelton, R. Billing, and R. Bohman. 1984. $\gamma$-Interferon induced expression of the HLA-D antigens on normal and leukemic human myeloid cells. Proc. Natl. Acad. Sci. USA. 81:4080-4084.

47. Koeffler, H.P. 1983. Study of normal and abnormal hematopoiesis using human leukemic cell lines. UCLA Symposium on Molecular and Cellular Biology. New series. Alan R. Liss Inc., New York. 19:179-195.
48. Warrell, R.P., Jr., H. de Thé, Z.Y. Wang, and L. Degos. 1993. Acute promyelocytic leukemia. N. Engl. J. Med. 329:177-189.

49. Midland, M.M., Y. Plumet, and W.H. Okamura. 1993. Effect of C20 stereochemistry on the conformational profile of the side chains of vitamin D analogs. Bioorg. Med. Chem. Lett. 3:1799-1804.

50. de Thé, H., A. Marachio, P. Tiollais, and A. Dejean. 1989. Differential expression and ligand regulation of the retinoic acid receptor $\alpha$ and $\beta$ genes. EMBO (Eur. Mol. Biol. Organ.) J. 8:429-433.

51. Hoshimoto, Y., H. Kagechika, and K. Shudo. 1990. Expression of retinoic acid receptor genes and ligand-binding selectivity of retinoic acid receptors (RARs). Biochem. Biophys. Res. Commun. 166:1300-1307.

52. Kastner, P., A. Perez, Y. Lutz, C. Rochette-Egly, M.-P. Gaub, R. Berger, and P. Chambon. 1992. Structure, localization and transcriptional properties of two classes of retinoic acid receptor $\alpha$ fusion proteins in acute promyelocytic leukemia (APL): structural similarities with a new family of oncoproteins. EMBO (Eur. Mol. Biol. Organ.) J. 11:629-635.

53. Weis, K., S. Rambaud, C. Lavau, J. Jansen, T. Carvalho, M. Carmo-Fonseca, A. Lamond, and A. Dejean. 1994. Retinoic acid regulates aberrant nuclear localization of PML-RAR $\alpha$ in acute promyelocytic leukemia cells. Cell. 76:345-356.

54. Perez, A., P. Kastner, S. Sethi, Y. Lutz, C. Reibel, and P. Chambon. 1993. PML/RAR homodimers: distinct DNA binding properties and heteromeric interactions with RXR. EMBO (Eur. Mol. Biol. Organ.) J. 12:3117-3182.

55. Carlberg, C., Y.S. Mathiasen, Y.H. Saurat, and L. Binderup. 1994. The 1,25-dihydroxyvitamin $\mathrm{D}_{3}$ (VD) analog MC903, EB1089 and KH1060 activate the VD receptor: homodimers show higher ligand sensitivity than heterodimers with retinoid X receptors. J. Steroid. Biochem. Mol. Biol. 51:137-142.

56. Peleg, S., M. Sastry, E. Collinst, Y.E. Bishop, and A.W. Norman. 1995. Distinct conformational changes induced by 20-epi analogs of 1 $\alpha, 25$-dihydroxyvitamin $\mathrm{D}_{3}$ are associated with enhanced activation of the vitamin $\mathrm{D}$ receptor. $J$. Biol. Chem. 270:3-8.

57. Dawson, M.I., E. Elstner, D. Chen, B. Kerner, and H.P. Koeffler. 1994 Myeloid differentiation mediated through RAR/RXR not RXR/RXR pathway. Blood. 84:446-452.

58. Kizaki, M., M.I. Dawson, R. Heyman, E. Elstner, R. Marosetti, S. Pakkala, D.L. Chen, H. Ueno, M. Morikawaq, Y. Ikeda, et al. 1996. Effects of novel retinoic $\mathrm{X}$ receptor (RXR) specific ligands on myeloid leukemic differentiation and proliferation in vitro. Blood. 89:1977-1984.

59. Fanjul, A., M.L. Dawson, P.D. Hobbs, L. Jong, J.F. Cameron, E. Harley, G. Graupner, X.P. Lu, and M. Pfahl. 1994. A new class of retinoids with selective inhibition of AP-1 inhibits proliferation. Nature (Lond.). 372:107-110.

59a. de Vos, S., M.I. Dawson, S. Holden, T. Le, A. Wang, S.K. Cho, K.L. Chen, and H.P. Koeffler. 1997. Effects of novel, potent retinoid X receptor (RXR) specific ligands and ligands with anti-AP-1 activity on proliferation of prostate cancer cells. Prostate. In press.

60. Gianni, M., M. Terao, S. Zanotta, T. Barbui, A. Rambaldi, and E. Garattini. 1994. Retinoic acid and granulocyte colony-stimulating factor synergistically induce leukocyte alkaline phosphatase in acute promyelocytic leukemia cells. Blood. 83:1909-1921,

61. Brackman, D., F. Lung-Johansen, and D. Aarskog. 1995. Expression of cell surface antigens during the differentiation of HL-60 cells induced by 1,25dihydroxyvitamin $\mathrm{D}_{3}$ retinoic acid and DMSO. Leuk. Res. 19:57-64

62. Todd, R.F., L.M. Nadler, and S.F. Schlossman. 1981. Antigens on human monocytes identified by monoclonal antibodies. J. Immunol. 126:14351442 .

63. Todd, R., and S.F. Schlossmann. 1982. Analysis of antigenic determinants on human monocytes and macrophages. Blood. 59:775-780.

64. Wright, S.D., R.A. Ramos, P.S. Tobias, R.J. Ulevitch, and J.C. Mathison. 1990. CD14, a receptor for complexes of lipopolysaccharide (LPS) and LPS binding protein. Science (Wash. DC). 249:1431-1433.

65. Carlos, T.M., and J.M. Harlan. 1994. Leukocyte-endothelial adhesion molecules. Blood. 84:2068-2101.

66. Amatruda, T.A., R. Bohman, J. Ranyard, and H.P. Koeffler. 1987. Pattern of expression of HLA-DR and HLA-DQ antigens and mRNA in myeloid differentiation. Blood. 69:1225-1236.

67. Hu, Z.B., W. Ma, C.C. Uphoff, M. Lanotte, and H.G. Drexler. 1993. Modulation of gene expression in the acute promyelocytic leukemia cell line NB4. Leukemia (Baltimore). 7:1817-1823.

68. Khanna-Gupta, A., K. Kolibaba, T. Zibello, and N. Berliner. 1994. NB4 cells show bilineage potential and an aberrant pattern of neutrophil secondary granule protein gene expression. Blood. 84:294-302.

69. Ruchaud, S., E. Duprez, M.C. Gendron, G. Houge, H.G. Genieser, B. Jastoff, S.O. Doskeland, and M. Lanotte. 1994. Two distinctly regulated events, priming and triggering, during retinoid-induced maturation and resistance of NB4 promyelocytic leukemia cell line. Proc. Natl. Acad. Sci. USA. 91:8428.

70. Hockenbery, D.M. 1992. The bcl-2 oncogene and apoptosis. Semin. Immunol. 4:413-420.

71. McDonnell, T.J., N. Deane, F.M. Platt, G. Nufiez, U. Jaeger, J.P. Mc Kearn, and S.J. Korsmeyer. 1989. Bcl-2 immunoglobin transgenic mice demonstrate extended B cell survival and follicular lymphoproliferation. Cell. 57:79-88.

72. Martin, S.J., J.G. Bradley, and T.G. Cotter. 1990. HL-60 cells induced to differentiation towards neutrophils subsequently die via apoptosis. Clin. Exp. Immunol. 79:448-453. 